\title{
PAPERS PUBLISHED IN JOURNAL OF COMPUTER SCIENCE AND CYBERNETICS: 1984-2014
}

\author{
Volume 1, Number 1 (1985)
}

Lời giới thiệu - (Preface)

Phan Đình Diệu - Kỹ thuật vi xử lí, vi tin học và khả năng ứng dụng rộng rãi vào thực tiễn nước ta. (Microprosessors, micro computer and the probabilities of their wide applications in our country.)

Trần Vũ Thiệu - Về hai bài toán trên tập lồi đa diện. ( On two problems over polyhedral convex sets.)

Tạ Văn Đĩnh - Thay đổi miền của bài toán biên. (Changing the domain of a boundary value problem.)

Ngô Văn Lược, Tạ Hồng Quảng, Lê Kim Luật - Giải gần đúng bài toán thấm của hệ thống đập đất bằng phương pháp phần tử hữu hạn. (An approximate solution of the filtration problem of a system of the dams by the finite element method.)

Hồ Thuần, Lê Văn Bào - Các phép chuyển dịch lược đồ quan hệ. (Translations of relation schemas.)

\section{Volume 1, Number 2 (1985)}

Nguyễn Đình Tài, Phan Đình Diệu - Phân rã bài toán tối ưu phi tuyến không tách được bằng phương pháp phân cấp nhiều mức. (Decomposition of inseparable nonlinear optimization problems by the multilevel hierarchical method.)

Hoàng Chí Thành, Piotr Prószynski - Sự hợp thành của các quan hệ đồng thời và các mạng đơn được đánh dấu. (Composition of concurrency relations and marked simple nets.)

Nguyễn Trọng - Về bài toán đóng thùng mở rộng. (On a generalized problem of bin packing.)

Nguyễn Công Hóa - Về một quy trình người - máy phân tách cấu trúc thông tin - tổ chức trong quản lí và kế hoạch hóa. (On a man - machine procedure to be used in decomposing the structure of organization - information in the management and planning.)

Giới thiệu sách - (Book review.)

Nguyễn Huy Mỹ - Hội Quốc tế về Điều khiển tự động IFAC. (International Federation of Automatic control.)

Tin tức hoạt động - (News)

Volume 1, Number 3 (1985)

Nguyễn Xuân Huy - Toán tử đánh nhãn và các phép toán quan hệ. (A labeling operator and relational operations.)

Đỗ Văn Sỹ, Bùi Thế Tâm, Nguyễn Văn Thiều - Một phương pháp xác định hệ số chi phí trực tiếp của bảng cân đối lien ngành. (On the method for estimating technical coefficients of input-output analysys model.)

Đỗ Xuân Thọ, Đinh Thị Ngọc Thanh - Hệ TN - 82. (TN - 82 - a relational database management system.) 
Nguyễn Bường - Về chọn tham số hiệu chỉnh cho phương trình Hammerstein. (On the selection of the regularization parameter for Hammerstein' equation.)

Nguyễn Chí Thành - Phương pháp MCA trong lưu trữ và tìm tin. (MCA method in information storage and retrieval.)

Nguyễn Chí Công, Trần Xuân Thuận - Hệ phát triển vi tính FT 68K. (Microcomputer development system FT $68 \mathrm{~K}$.)

Hội nghị toán học toàn quốc lần thứ 3. - (3rd national congress of mathematicians.)

\section{Volume 1, Number 4 (1985)}

Nguyễn Thanh Thủy, Nguyễn Xuân Huy - Về một thuật toán thực hiện phép chia trong mô hình quan hệ. (On some algorithms for the division in the relational data models.)

Nguyễn Văn Tâng - Về một phương pháp kết hợp ngôn ngữ dữ liệu với ngôn ngữ lập trình. (On a method combining the data language and the programming language.)

Lê Tiến Vương - Về áp dụng lí thuyết tập mờ trong mô hình quan hệ. (On the application of fuzzy set theory in relational database.)

Phạm Văn Lang, Nguyễn Huy Mỹ, Nguyễn Tuấn Anh, Trần Minh Châu, Lê Sỹ Hùng, Nguyễn Thái Hưng - Thư viện chương trình xử lí thông tin ban đầu, nhận dạng đặc tính động học, chọn chế độ làm việc hợp lí và tính toán thiết kế liên hợp máy nông nghiệp. (The program packages for primer information processing, identification of the dynamic characteristic, choosing optimal working regime and design of the agricultural machins.)

Phạm Hải Bắc - Vấn đề mở rộng đại số quan hệ. (An approach to expanding relational algebra.)

Nguyễn Huy Mỹ - Viện các vấn đề về điều khiển. (Institute of control problems.)

Trao đổi - (Brief)

Vũ Duy Mẫn - Tăng tốc độ thực hiện các chương trình BASIC. (Speed up the execution of the BASIC program.)

Giới thiệu sách - (Book review)

\section{Volume 2, Number 1 (1986)}

Vũ Như Lân - Một phương pháp rút gọn tính toán ma trận hiệp phương sai trong việc ước lượng trạng thái của các hệ lien tục với quan sát rời rạc (On a simplified method for computing the conanance matrix in state estimation of continuous - time systems from discrete measurements)

Hoàng Trung Du - Độ phức tạp tính toán của một số thuật toán nội suy hàm hai biến (Computational complexity of some algorithms for interpolation of bivariate functions)

Nguyễn Ngọc Kiên - Về tương đương giữa các chương trình nguồn và vấn đề khôi phục dạng nguồn (On the equivalence between surce programs and the problem of recovery of source)

Đỗ Minh Thái - Thiết kế và cài đặt chương trình điều khiển terminal vi tính chuyên dụng MP1000 vào hệ điều hành máy tính MINI16 (Design and implementation of the program system controlling the special purpose microcomputing terminal MP1000 to the operating system of the computer MINI16)

Nguyễn Hiền, Nguyễn Văn Thiều - Một cách tiếp cận vấn đề phân bố vốn và lao động theo ngành và lãnh thổ (An approach to the problem of investement and labour distribution)

Nguyễn Công Điều, Hoàng Văn Lai, Nguyễn Lê Thu - Một số thuật toán và chương trình giải hệ phương trình đại số tuyến tính với ma trận thưa cỡ lớn (Some algorithms and a pagekage for large sparse matrices)

Thông báo - (Information) 


\section{Volume 2, Number 2 (1986)}

Lê Ngọc Lăng - Về sự tồn tại và duy nhất nghiệm của một lớp các phương trình toán tử (Existence and uniqueness theorems for a class of nonlinear operator equation)

Nguyễn Bường - Về nghiệm của phương trình Hammerstein với các toán tử đơn điệu gián đoạn (On the solution of Hammersteins equation with discontinuous monotones operators)

Phan Đăng Cầu - Bài toán ngược của phương trình nhân chập hai chuỗi thời gian và ứng dụng (The inverse problem of the convolution equation for two time series and application)

Hồ Hữu Nam, Nguyễn Văn Quỳ - Mô hình hóa về chiến lược phát triển cây công nghiệp lâu năm (Modelling of strategie development of perennial technical crops)

Trần Thái Sơn, Đinh Thị Ngọc Thanh - Một số kết quả về cấu trúc của phủ tối thiểu trong mô hình cơ sở dữ liệu dạng quan hệ (Some results on structures of a minimum cover in the relational database model)

Nguyễn Văn Tam, Trần Xuân Thuận, Phạm Quang Oai, Vũ Duy Lợi - Các tấm chuẩn của hệ vi xử lí (The standard boards of microprocessor system VT)

\section{Volume 2, Number 3 (1986)}

Nguyễn Thanh Thủy - Về một thuật toán cài đặt cải biên nhóm phép tính CHIẾU-CHỌN-NỐI (Some modifield implementation algorithms for the generalized operation PROJECTION-SELECTIONJOIN and their complexities)

Lê Văn Bào - Quan hệ giữa khóa của hàm đóng và khóa của lược đồ quan hệ (On the accordance between the keys of closed function and the keys of relation schema)

Ngô Quốc Tạo, Hoàng Kiếm - Một số kết quả về hiệu quả của thuật toán nhận dạng tổ hợp (Some results of the efficiencies of the combined pattern recognition algorithm)

Phạm Ngọc Khôi - Một cách tiếp cận việc biểu diễn ảnh của đối tượng qua bóng của nó (An approach to represent image objects by shaps)

Đỗ Xuân Thọ - Về tương đương của các biểu mở rộng đơn (Equivalences among simple generalized tableaux)

Nguyễn Chí Công - Về một bộ chương trình tiện ích xây dựng trên hệ phát triển vi tính FT 68K (On an utility realized on the FT 68K)

Tin tức hoạt động - (News)

Giới thiệu sách - (Book review)

\section{Volume 2, Number 4 (1986)}

Lê Ngọc Lăng - Sự tồn tại và duy nhất nghiệm của một lớp các bài toán giá trị ban đầu dạng phương trình tiến hóa (Existance and uniqueness theorems for a class of initial value problem)

Nguyễn Thúc Loan, Hoàng Hồng Sơn, Vũ Như Lân, Nobert Ahlbeh-renndt - Về một bài toán không chính xác định thông số hệ chịu tác động nhiễu với các quan sát rời rạc. Phần I: biết cấu trúc bậc hệ (On the ill-posed problems of the parameter identification for the stochastics systems with discrete observations)

Phan Đăng Cầu - Phương pháp bình quân cực tiểu và vấn đề lọc nhiễu đối với một lớp tín hiệu ngẫu nhiên không dừng (Least square method and the filtering problem of nonstationary signal)

Nguyễn Công Điều, Hoàng Văn Lai, Nguyễn Lê Thu - Về phương pháp Gauss với ma trận thưa cỡ lớn (On the method Gauss for large sparse matrices)

Nguyễn Viết Thanh, Bùi Thế Tâm, Trần Vũ Thiệu - Phương pháp xác định cơ cấu hợp lí các nguồn nhiên liệu năng lượng có tính đến ảnh hưởng của những hộ tiêu thụ lớn (A method for 
determining the relational structure of a fuel energetic system taking into consideration the main consumers)

\section{Volume 3, Number 1 (1987)}

Hồ Thuần - Cơ sở dữ liệu quan hệ đặc trưng và triển vọng (tổng quan). (The relational database - speciality and expectation.)

Lê Thiện Phố - Về sự hội tụ của một sơ đồ sai phân đối với bài toán biên phi tuyến loại parabol. (On the convergence of a finite difference scheme for a nonlinear boundary problem of parabolic type.)

Nguyễn Đình Tài - Một phương pháp biểu diễn hàm toàn phương thành hiệu hai hàm lồi. (A representation method of a quadratic function in the form of the difference of two convex functions.)

Lương Chi Mai - Một mô hình biểu diễn ảnh và phương pháp phân loại nhanh sử dụng các cấu hình tương tự. (Model of image representation and classification algorithm using analog configurations.)

Tin tức hoạt động - (News)

Đặng Văn Đức - Một phương pháp xây dựng phần mềm cho hệ vi xử lí ứng dụng thời gian thực. (A method of designing software for real - time application system on the basis of microprocessor.)

Trao đổi - (Brief)

\section{Volume 3, Number 2 (1987)}

Lê Tiến Vương - Phép tách suy biến của một quan hệ trong cơ sở dữ liệu. (Degenerate decomposition of a relation in database.)

Trần Thọ Đạt, Vũ Quốc Huy - Phương pháp san số mũ trong dự đoán dãy chỉ tiêu kinh tế. (The method of exponential smoothing in forecasting economic series.)

Tạ Văn Tự - Về một lớp mô hình tối ưu và ứng dụng. (On the class of optimal model and their application.)

Phạm Huy Thỏa, Đặng Thành Phu, Phạm Thượng Cát - Đo tự động nồng độ clor trong nước. (An apparatus for automatical measuring densyty of clor in the water.)

Phí Mạnh Lợi - Mô phỏng đụng độ trong mạng cục bộ Ethernet. (Collision generator.)

Ngô Trung Việt - Vấn đề chữ Việt trên máy tính. (The problem of Vietnamese words on computers.)

Đào Hữu Chí, Lê Mạnh - Một phương án thiết kế cài đặt bộ chữ Việt trên máy vi tính. (A project for the installation of the Vietnamese language on micro computers.)

Phan Đình Diệu - Giới thiệu các đề án khoa học phức hợp nghiên cứu tin học trong phạm vi hợp tác của viện HLKH các nước XHCN. ()

\section{Volume 3, Number 3 (1987)}

Đỗ Việt Nga - Một số phương pháp tự động hóa tổng hợp văn bản. (Some methods of document automatic synthesis.)

Nguyễn Văn Tam - Tấm CPU - Z80 trên bus VT - 64. (Card CPU - Z80 on the bus VT - 64.)

Nguyễn Văn Lư, Hồ Thuần - Cài đặt ngôn ngữ PADRE bằng kỹ thuật tiền xử lí. (On the PADRE' s implementation by preprocessor technique.)

Nguyễn Ngọc Kiên, Đoàn Thanh Vịnh, Vũ Duy Mẫn - Thực hiện lien tục cấp thấp trong xây dựng hệ đa xử lý từ hai máy tính mini 16. (Relisation of low-level communication in construction of the multi-processing system from two computers mini 16.) 
Nguyễn Như Cận - Hệ TV - 86. (System TV - 86.)

Nguyễn Chí Công - PS/2 và những tiêu chuẩn tương lai. (PS/2 and standards in future.) 23

Hồ Thuần - Hội thảo công nghệ phần mềm.

Giởi thiệu sách -

Lập trình song ngữ PASCAB - BASIC của Nguyễn Xuân Huy.

Ngữễ̂n Xuân Huy - Về các tiêu chuẩn sản phẩm phần mềm. (On the norms of evaluation of software products.)

Giới thiệu hội thảo quốc tế về toán học tại Tp HCM, tháng 4-1988

\section{Volume 3, Number 4 (1987)}

Vũ Đình Hòa, Đoàn Phúc - Bài toán luồng và ứng dụng trong thực tế. (The problem of flow and its application.)

Nguyễn Xuân Huy, Bùi Quang Ngọc - Hệ GP. (GP system.)

Nguyễn Thanh Tùng - Tối ưu và thuật toán lấy mẫu kiểm tra. (Optimazation and algorithm for a sampling inspection problem.)

Đặng Văn Đức - Một số phương pháp bảo vệ tệp trên IBM-PC. (Some methods for the file protection on IBM-PC.)

Trao đổi - (Brief)

Đỗ Việt Nga - Bàn về bố trí bàn phím tiếng Việt. (On the lay-out of the Vietnamese keyboard.)

Nguyễn Huy Tú - Về việc đưa tin học vào trường phổ thông. (On the education of informatics in the schools.)

Thông báo - (Informations)

Volume 4, Number 1 (1988)

Trần Thọ Châu - Bài toán tương đương ngôn ngữ trên lưới PETRI suy rộng (Language - equivalence problem on self-modifying-nets)

Nguyễn Văn Mạnh, Bùi Minh Trí, Nguyễn Thúc Loan - Phương pháp hướng phân giác giải bài toán tối ưu hóa không rang buộc tổng quát (Method of "bisector direction" for solving the unconstrained optimization problem)

Phạm Thế Quế - M- phủ tối thiểu và các hệ spener với vấn đề tìm kiếm khóa của quan hệ cơ sở dữ liệu (M-minimal cover and spener systems with application to the key finding problem for relation scheme)

Nguyễn Quang Hòa, Nguyễn Tuấn Hoa, Nguyễn Văn Hùng - Nghiên cứu và ứng dụng một phương pháp thống kê nhiều chiều trong y học (A study of a multi-dimensional statistical method and its application in biometry)

Lê Thành Lân - Nghiên cứu sơ bộ bước đầu về xây dựng hệ thống tự động hóa thiết kế (First results about the construction of the automatic design system)

Nguyễn Xuân Huy - Những quan niệm và nội dung công nghệ phần mềm trong khối SEV ()

\section{Volume 4, Number 2 (1988)}

Bùi Thế Tâm, Trần Túc - Phương pháp phân rã giải quy hoạch lõm (The decomposition method for concave programming)

Trần Thọ Châu - Bài toán NP-đầy đủ đối với lưới Petri suy rộng dạng SM (self-modifying-net) thuộc lớp PonceSM) (The problem NP-complete for self-modifying-net Petri belongs to the class PonceSM)) 
Lê Hồ Khánh - Hệ chuyên gia theo mô hình phân cấp cơ sở tri thức (Expert system based on the hierarchical model of knowledge base)

Trần Bá Thái, Phạm Mạnh Cổn - Một phương pháp xử lí in chữ Việt và chữ Nga cho các máy in kiểu EPSON-FX85, FX100, FX1000 (A method of treatment in printing Vietnamese and Russian letters for machines EPSON-FX85, FX100, FX1000)

Hoàng Kiếm - Công nghệ phần mềm và trí tuệ nhân tạo (Software engineering and artificial intelligence)

Tô Tuấn - R- công nghệ và tự động hóa lập trình (R technology and the automatic programming)

Tổ lập trình trung tâm máy tính ĐHBK - Vài nét về hệ chương trình tuyển sinh đại học, cao đẳng và trung học chuyên nghiệp (Some features of the program system for the competition of students to different universities and institutes)

\section{Volume 4, Number 3 \& 4 (1988)}

Lê Xuân Lam - Dự báo kết quả tác động của các chính sách lên một quần thể trong lý thuyết đổi mới. (On the prediction of impacting consequences policies on a population in the renewal theory.)

Nguyễn Chí Công - Về việc thiết kế một trình biên dịch ngôn ngữ C. (On designing a C compiler for MC68000.)

Võ Trung Châu - Phát hiện sai trong hệ thống kiểm tra bằng test xoay vòng cho các thiết bị số. (Faut detection in systems for cyclic testing of discrete devices.)

Nguyễn Văn Châu - Thiết bị đo nhiệt độ cao ORP-16 và ORP-16-IC. (Optiko radiant pyrometer ORP-16 and optiko radiant pyrometer for iron cacting ORP-16-IC.)

Dines Bjorner - Công nghệ phần mềm và lập trình. Quá khứ - Hiện tại - Tương lai. (Software engineering and programming. Past - Present - Future.)

Trần Bá Thái - Tiếng Việt và tin học - quan niệm, giải pháp, cài đặt. (Vietnamese language and informatic - conception, solution and implementation.)

\section{Volume 5, Number 1 (1989)}

Hoàng Văn Lai - Đánh giá chính xác chuẩn của ma trận nghịch đảo trong hệ phương trình xác định Spline loại IV. (The exact bounds of inverse matrix in the system of equations for Spline of type IV.)

Hồ Tú Bảo - Khái quát về trí tuệ nhân tạo và hệ chuyên gia. (An overview on artificial intelligence and expert systems.)

Hoàng Kiếm, Giang Vũ Thắng, Nguyễn Văn Điện - Một số phương pháp và thuật toán nhận dạng chữ. (Some effective methods and algorithms for the character recognition.)

Hồ Tú Bảo, Phạm Ngọc Khôi, Doãn Ngọc Liên, Đỗ Việt Nga - OREST - công cụ xây dựng hệ chuyên gia dựa trên biểu diễn đối tượng và luật. (OREST - a tool for building expert systems based on object - rule knowledge representation.)

Phan Đình Lợi, Huỳnh Ngọc Phiên, Bạch Hưng Khang - Chương trình mô phỏng canh tác nhờ nước mưa.

Lê Mạnh, Đậu Ngọc Hà, Phan Quang Thế - Hệ thống soạn thảo văn bản tiếng Việt WORDVN. (The program WORD - processing in Vietnamese language: WORDVN.)

Giới thiệu - Hội nghị quốc tế Avignon về hệ chuyên gia và ứng dụng. Các hội nghị nhận dạng quốc tế. 


\section{Volume 5, Number 2 (1989)}

Nguyễn Thúc Hải - Một số nét giới thiệu tổng quan về mạng máy tính. (Computer networks: an overview introduction.)

Trần Hoàng Yến - Đánh giá lời giải cận tối ưu bằng phương pháp đối ngẫu đối với bài toán min-max cho hệ điều khiển nhiều đầu vào. (Estimating suboptimal solutions to minimax problems for linear multi-input control systems by dual method.)

L.T. Vương, N.T. Bình - FAMEBASE Ver. 2.0 - hệ quản trị cơ sở dữ liệu cho người sử dụng đầu cuối. (FAMEBASE Ver. 2.0: a DBMS for end-users.)

Phí Mạnh Lợi - Truyền dẫn tín hiệu tương tự dồn kênh. (Possibility of the transmission of an analoy signal multiplexed from different time intervals.)

Nguyễn Tuấn Hoa, Vũ Duy Mẫn - Vai trò của thiết kế tổng thể trong ứng dụng tin học vào quản lý xí nghiệp.

\section{Volume 5, Number 3 (1989)}

Vũ Đình Hòa, Đoàn Phúc, Đào Đình Khả - Bài toán luồng và ứng dụng trong thực tế. (The problem of flow and its application.)

Lê Xuân Lam - Về bài toán thu hồi đầu tư và ứng dụng trong vay - thanh toán nợ. (On the problem of recovering investment and its application in loan-settling debts.)

Trần Doãn Tuấn - Một vài kết quả về các dàng buộc trên các giá trị không trong CSDL quan hệ. (Some results about cenotraints on null values in relational databases.)

Dương Tuấn Anh - Phép chuyển từ đặc tả ẩn tang thành chương trình logic. (A way to transform implicit specifications in to logic programs.)

Đặng Văn Đức - Bộ soạn thảo sơ đồ logic Sched trên máy vi tính IBM-PC. (Logic capture for logic simulation on IBM-PC.)

\section{Volume 5, Number 4 (1989)}

Phạm Thượng Cát - Điều khiển robot $n$ bậc tự do. (Control of n-degree-of freedom robot manipulator)

Phạm Huy Thỏa - Điều khiển thích nghi vị trí trên cơ sở kỹ thuật vi xử lý. Phần I: Hệ thống điều khiển vị trí nhờ quan sát và phản hồi trạng thái. (Adaptive position control bases on micro-computer.)

Nguyễn Thanh Tùng - Các phương án lấy mẫu kiểm tra kinh tế với ba quyết định. (Cost-optimal attributes acceptance sampling plans with three decision criteria.)

Chu Văn Hỷ - Phương pháp mới tính hàm truyền rời rạc của phần lien tục trong hệ thống điều khiển số. (A new method for calculating the discrete transfer function of the continuous part in digital control systems.)

Lê Trường Tùng - Một số bài toán đảo ngẫu nhiên có hạn chế. (Some random permutation problems with restrictions.)

\section{Volume 6, Number 1 (1990)}

Bạch Hưng Khang - Về nghiên cứu khoa học và công nghệ tin học. (About scientific research and technology of informatics.)

Lê Xuân Quảng - Giải bài toán Carleman suy rộng trên trục thực bằng phương pháp chiếu lặp trên cơ sở phép chiếu bình phương tối thiểu. (Projection-iteractive method is used for Carleman problem.) 
Hồ Văn Tích - Ánh xạ cơ sở dữ liệu, các bài toán tách và cập nhật độc lập. (Data base mappings, the problems of decomposition and independent updates.)

Vũ Như Lân, Hoàng Hồng Sơn - Quan điểm chỉnh hóa trong ước lượng và điều khiển hệ động lực.

Giới thiệu, tin tức - (News and references)

Volume 6, Number 2 (1990)

Ngô Trung Việt - Về xây dựng hệ thống tin văn phòng. (About the office information systems.)

Lê Tự Thành - Nhận dạng đường cong tín hiệu theo cách tiếp cận xử lý ảnh một chiều. (Signal recognition by using one-dimention image processing approach.)

Đặng Quang Á - Xây dựng lược đồ sai phân suy rộng tựa đơn điệu có độ đúng cấp cao cho một số phương trình. (Construction of quasimonotone generalized difference schemes having high order of accuracy for some equations.)

Hoàng Kiếm, Nguyễn Ngọc Kỷ - Biểu diễn tự động ảnh đường nét. (Automatic representation of digital lines.)

\section{References}

\section{Volume 6, Number 3 (1990)}

Nguyễn Quý Hỷ, Lê Xuân Lam - Áp dụng lý thuyết đổi mới trong quản lý giá trị - kho hang hóa. (On the model for manage of the value - goods.)

Nguyễn Bường - Về hiệu chỉnh bất đẳng thức biến phân trong không gian $L_{p}(\cap)$. (On regularization for variational inequality in $\left.L_{p}(\cap)\right)$.)

Lương Chi Mai - Ma trận toeplitz và mã bình phương tối thiểu cho các đường cong số hóa. (Toeplitz matrices and least - squares coding.)

Tống Thị Thanh Huyền, Hồ Tú Bảo - Một thuật toán tổng quát hóa. (A generalization algorithm.)

Trần Đình Khang, Hoàng Kiếm - Một phương pháp xây dựng hệ soạn thảo và phân tích công thức toán học. (A method implementing mathematical formular editor and analyzer.)

\section{Volume 6, Number 4 (1990)}

Ngô Quốc Tạo, Hoàng Kiếm - Thuật toán nhận dạng thích nghi các đối tượng trong hệ thị giác máy. (An adaptive recognition algorithm for vision systems.)

Giang Vũ Thắng - Các thuật toán quy hoạch động song song để nhận dạng ảnh dựa trên đường biên. (Parallel dynamic programming algorithms for image recognition based on its contour.)

Nguyễn Ngọc Kỷ - Một vài khía cạnh lý thuyết của các thuật toán dò biên. (On some bound following algorithms.)

Lê Tự Thành - Một phương pháp cấu trúc mạng ngữ nghĩa. (On method for designing of sematic network.)

Vũ Đức Thi, Nguyễn Kim Anh - Các phụ thuộc yếu trong mô hình dữ liệu quan hệ. (Weak dependencies in the relational model of data.)

\section{Volume 7, Number 1 (1991)}

Lê Xuân Lam - Kế hoạch hóa quản lí cán bộ bằng lý thuyết đổi mới. (Planning and administrative affairs of the cader in the renewal theory.)

Đinh Thị Ngọc Thanh - Phụ thuộc hàm trong cơ sở dữ liệu quan hệ mở rộng. (Functional dependencies in the extended relational database.)

Nguyễn Bá Tường - Một số khái niệm của các hệ tìm kiếm và lưu trữ thông tin. (Some properties of information storage and retrieval systems.) 
Đoàn Văn Ban, Giang Vũ Thắng, Ngô Quốc Tạo - Thiết kế và cài đặt hệ quản trị và xử lý dữ liệu ảnh: DIMS. (On the design and implementation of data-image management system.)

Nguyễn Hồng Quang, Hoàng Ngọc Hùng - Bộ chương trình SYSPRO. (Paket of programs SYSPRO.)

\section{Volume 7, Number 2 (1991)}

Đoàn Văn Ban, Nguyễn Ngọc Thuần - Thuật toán Systolic cho các phép toán cơ sở dữ liệu. (The Systolic algorithms for relational database operations.)

Phan Đăng Cầu - Vài nhận xét về việc ứng dụng lý thuyết quá trình dừng để xử lý các tín hiệu số. (Some remarks on the applications of the theory of stationary processes in processing digital signals.)

Đặng Văn Hưng - Một mô hình để biểu diễn hành vi và phân tích các hệ thống phân tán. (A model for analyzing distributed systems.)

Nguyễn Thúc Hải - Một mô hình cài đặt các giao thức truyền thông trên mạng máy tính. (A model for implementing network protocol software.)

Tin tức - (New)

\section{Volume 7, Number 3 (1991)}

Lê Tự Thành, Hoàng Kiếm - Khảo sát đường cong tín hiệu bằng phường pháp Delta và kỹ thuật nhóm điểm. (To study the signal curves by the Delta method and the point cluster.)

Đỗ Hồng Anh, Hoàng Kiếm - Một cách giải bài toán dựa trên mạng ngữ nghĩa các công thức. (A problem solver based on the formular network.)

Phan Chí Vân - Lược đồ logic đối xứng và ứng dụng. (On the concept of the logical symmetric scheme.)

Lê Huy Thập - Mô hình kinh tế vi mô với tiến bộ kỹ thuật công nghệ và vấn đề điều khiển tối ưu. (Microeconomic model with ecological technical progress and optimal control problem.)

Lê Mạnh - Hệ GT90- một hệ quản trị cơ sở dữ liệu khai thác theo thời gian thực. (The system GT90- management base on data operating on real-time.)

Giới thiệu, tin tức - (Refernces, news.)

\section{Volume 7, Number 4 (1991)}

Hoàng Kiếm, Nguyễn Mạnh Quyền - Một phương pháp xử lý các biểu thức số học trong các hệ trợ giúp tính toán không cần lập trình. (One method for numeric string processing in the tutor of intelligent and non-programable computing.)

Lê Minh Hùng, Phạm Khắc Huy - Phương pháp xây dựng thuật toán điều khiển robot tọa độ cầu khớp phẳng trên mô hình động học theo ba phương X, Y, Z. (Method to build the algorithm to control the robot on the dynamic model with plane - spherical co-ordinate by three dimentions $\mathrm{X}$, Y, Z.)

Nguyễn Hoàng Phương - Xây dựng các hệ tri thức y học cổ truyền Việt Nam. (Development of traditional Vietnamese medical knowledge systems.)

Huỳnh Hữu Nghĩa - Về các phép mã hóa hợp lý trong tiến trình thiết kế mô hình cơ sở dữ liệu. (On logical coding methods in process of designing of relational scheme.)

Phan Chí Vân - Ứng dụng của lược đồ logic đối xứng. (The applications of the logical symmetric scheme.) 


\section{Volume 8, Number 1 (1992)}

Lê Bá Dũng, Phạm Thượng Cát - Một số vấn đề cơ bản trong việc thiết kế bộ điều khiển trên cơ sở hệ luật.

Nguyễn Văn Châu - Ứng dụng phương pháp tiệm cận hệ thống trong điều khiển quá trình công nghệ nhiệt diện.

Trần Đình Khang, Nguyễn Quang Sơn, Hoàng Kiếm - Xây dựng hệ trợ giúp tính toán thông minh.

Lê Xuân Quảng - Phương pháp chiếu lặp giải phương trình tích phân kỳ dị với nhân Hilbert trong không gian $L_{2}$.

\section{Volume 8, Number 2 (1982)}

Trần Thái Sơn - Về các quan hệ tối giản ở dạng không chuẩn một.

Đoàn Văn Ban, Đặng Văn Hưng - How much information of con-currency can be got from firing sequences in Petri Nets.

Ho Tu Bao, Dao Nam Anh - Coupling of knowledge and data in TESOR system.

\section{Volume 8, Number 3 (1992)}

Huỳnh Thúc Cước, Trần Bá Thái, Ngô Trung Việt - Nghiên cứu tin học trong điều khiển các quá trình công nghệ tại nhà máy xi măng Hoàng Thạch.

Phan Dang Cau - On prediction and filtering problem of long run stationary time series.

Dang Van Hung - Labelled transition system approach to distributed computing systems.

\section{Volume 8, Number 4 (1992)}

Vũ Như Lân, Đặng Thành Phu, Vũ Chấn Hưng - Nhận dạng bậc hệ động lực.

Chu Văn Hỷ - Hệ thống điều khiển tối ưu bình phương với ảnh hưởng của thời gian tính.

Hoang Chi Thanh - On behavioural synchronization in net systems.

\section{Volume 9, Number 1 (1993)}

Nguyễn Xuân Huy - On a new class of Boolean dependencies.

Phan Minh Tân - Một số vấn đề cơ bản của hệ điều hành thời gian thực.

Đoàn Phan Tân - Mô phỏng quá trình phục vụ người đọc ở một thư viện.

\section{Volume 9, Number 2 (1993)}

Nguyễn Văn Châu - Tiếp cận hệ thống điều khiển các quá trình công nghệ.

Nguyễn Công Điều - Giải số bài toán ô nhiễm khí bằng phương pháp luân hướng.

Đào Thị Hồng Hạnh - Về một phương pháp điều khiển truy nhập trong cơ sở dữ liệu. 


\section{Volume 9, Number 3 (1993)}

Phạm Thượng Cát - Vài nét tổng quan về những tiến bộ kỹ thuật trong lĩnh vực xây dựng mạng xử lý tin quốc gia.

Đặng Quang Á - Accelerated methods for solving grid equation I.

Volume 9, Number 4 (1993)

Nguyễn Cát Hồ, Trần Thái Sơn - Lôgic mờ và quyết định mờ dựa trên cấu trúc thứ tự của giá trị ngôn ngữ.

Hoàng Kiếm, Trần Vĩnh Phước - Một vài khía cạnh thuật toán của các kỹ thuật lọc và làm rõ đường biên trong xử lý ảnh.

Phan Minh Tân - Một số vấn đề cơ bản của hệ điều hành thời gian thực.

Ngô Quốc Tạo - Extracting invariants based on coordinate transformations.

\section{Volume 10, Number 1 (1994)}

Phạm Thượng Cát, Vũ Như Lân, Nguyễn Thế Thắng - Một số nét về phòng tự động hóa hiện nay ở nước ta.

Lê Bá Dũng - Thiết kế bộ điều khiển thông số PID trên cơ sở hệ luật.

Vũ Chấn Hưng - Về một thuật toán đánh giá bậc hệ động lực tuyến tính.

Tô Cẩm Tú - Hàm sản xuất một mức với nhịp độ tăng năng suất tới hạn phụ thuộc mọi nhận tố sản xuất.

Ngô Trung Việt, James Do, Ngô Thanh Nhàn, Hoàng Công Thành - Về bàn phím máy tính cho chữ Việt.

\section{Volume 10, Number 2 (1994)}

Phan Dinh Dieu, Tran Dinh Que - Reasoning in knowledge bases with external and internal uncertainties.

Nguyễn Nam Hải - Một sơ đồ mới nhằm tăng độ sẵn sang trong các hệ cơ sở dữ liệu phân tán.

Doan Nguyen Hai - A formula for creation and its applications to generate plots on computers.

Huỳnh Hữu Nghĩa - Về các phép mã hóa hợp lý.

Vũ Đức Thi - Một số kết quả trên phụ thuộc mạnh.

Tô Cẩm Tú - Tính lồi - lõm của hàm sản xuất một mức với độ co giãn thay thế không đổi.

\section{Volume 10, Number 3 (1994)}

Phan Dinh Dieu, Phan Hong Giang - Interval-valued probabilistic logic programs.

Vũ Chấn Hưng - Điều khiển tự thích nghi hệ động lực tuyến tính có cấu trúc và thông số không biết trước.

Lương Chi Mai - Parallel object classification algorithms in images.

Lều Đức Tân - Mở rộng lớp các số Mersenne. 


\section{Volume 10, Number 4 (1994)}

Dao Nam Anh - Knowledge based refinement.

Vũ Ngọc Loãn, Nguyễn Xuân Huy - Về định lý tương đương trong lớp các phụ thuộc Bool dương đa trị.

Đào Thị Hồng Hạnh - Một phương pháp điều khiển truy nhập trong hệ thống bảo vệ thông tin cơ sở dữ liệu.

Nguyễn Văn Mạnh - Về một phương pháp điều khiển cực trị hội tụ nhanh.

Ung Ngọc Quang - Về một xấp xỉ ước lượng Bayes trong mô hình thống kê phi tuyến.

Lê Xuân Quảng - Phương pháp chiếu lặp giải phương trình tích phân kỳ dị loại III.

\section{Volume 11, Number 1 (1995)}

Nguyễn Văn Châu - Điều khiển các dây truyền sản xuất linh hoạt.

Nguyễn Cát Hồ, Trần Thái Sơn - Về khoảng cách giữa các giá trị của biến ngôn ngữ trong đại số gia tử.

Chu Văn Hỷ - Điều khiển giá đảm bảo các hệ thống với thông số bất định.

Nguyễn Văn Mạnh - Một phương pháp tần số ứng ra của hệ tự động tuyến tính không dung bảng H- hàm số.

Nguyen Canh Toan, Do Van Lap - On the method of state invariance.

\section{Volume 11, Number 2 (1995)}

Đặng Quang Á - Accelerated method for solving grid equations, II (3-D case).

Nguyễn Cát Hồ, Lê Thế Thăng - Ngữ nghĩa của dữ liệu trong cơ sở dữ liệu với thông tin không đầy đủ.

Vũ Như Lân, Vũ Chấn Hưng, Hoàng Hồng Sơn - Lọc và nhận dạng thích nghi tối ưu trong bài toán điều khiển hệ ngẫu nhiên.

Hoàng Trung Lập - Sử dụng hệ CAPPA cho việc xây dựng kế hoạch phát triển nông nghiệp Việt Nam.

Nguyen Canh Toan, Do Van Lap - On the method of state invariance.

\section{Volume 11, Number 3 (1995)}

Nguyễn Văn Châu - Ứng dụng phương pháp thành phần đối xứng trong nghiên cứu các hệ hai kênh.

Nguyễn Hải Châu - Xây dựng một thủ tục truyền số liệu song công.

Vũ Thanh Hà - Thuật toán giải bài toán điều khiển tối ưu với dàng buộc dạng alternative.

Nguyễn Cát Hồ - Fuzzy logic, deductive rules of inference and linguistic reasoning on knowledge base.

Nguyễn Thanh Thủy - Thiết kế và cài đặt hệ nén dữ liệu thông minh IDCS.

Phạm Quang Trung, Nguyễn Xuân Huy - Cài đặt các thuật toán bảo đảm tính nhất quán dữ liệu cho mô hình cơ sở dữ liệu quan hệ.

Cao Đình Triều - Mô hình mật độ vỏ trái đất trên lãnh thổ Việt Nam. 


\section{Volume 11, Number 4 (1995)}

Nguyen Buong - On monotone ill-posed problems in Hilbert spaces.

Le Ba Dung - A kind of self-tuning pid controller.

Nguyễn Nam Hải, Phí Mạnh Lợi - Ứng dụng cơ sở dữ liệu vào quản lý và kiểm soát hệ thống điện quốc gia.

Chu Văn Hỷ - Điều khiển bền vững tối ưu bình phương với phản hồi đầu ra.

Vũ Đức Thi - On the equivalent descriptions of family of functional dependencies in the relational datamodel.

Vũ Đức Thi - Some problems related to primitive maximal dependencies.

Ung Ngọc Quang - Về ước lượng Bayes của phương sai trong mô hình thống kê.

\section{Volume 12, Number 1 (1996)}

Đặng Văn Đức - Nâng cao chất lượng in trên máy in.

Nguyễn Cát Hồ, Huỳnh Văn Nam - Lattice character of the refinement structure of hedge algebras.

Nguyễn Trung Hòa - Về một thuật toán mô phỏng mô hình tự hồi quy AR(p).

Trần Đình Khang - So sánh suy diễn mờ và suy luận ngôn ngữ.

Lê Hùng Lân - Phương pháp tổng hợp bộ điều chỉnh robot PID thông qua phân rã D.

Lê Thành Lân - Một vài mô hình nạp ngũ hành cho các cặp can chi.

Vũ Ngọc Phàn - Tính bền vững của các hệ điều khiển nhiều đầu vào nhiều đầu ra.

\section{Volume 12, Number 2 (1996)}

Nguyễn Văn Châu - Ứng dụng hàm nhậy loga đánh giá dự trữ ổn định các hệ điều khiển một vòng với thông số biến đổi theo thời gian.

Lê Bá Dũng - Một mô hình toán học của bộ điều khiển mờ với việc bổ sung tri thức và đầu ra là một tập lồi.

Đặng Văn Đức - Một vài phương pháp hiệu chỉnh dữ liệu bản đồ hóa.

Bạch Hưng Khang, Ngô Quốc Tạo, Phạm Ngọc Khôi, Lương Chi Mai, Đỗ Năng Toàn, Nguyễn Đức Dũng, Vũ Văn Thịnh - An examination of techniques for raster-to-vector process and implementation of software of software package for automatic map dataentry-mapscan.

Nguyễn Thanh Thủy - Thiết kế các ngôn ngữ mô tả và xây dựng cơ sở tri thức cho các phần mềm trợ giúp giải bài toán hình học.

Cao Đình Triều - Revelation of seismogenic zones after geological and geophysical data.

Phan Chí Vân - Khái niệm về mô hình logic đối xứng - hệ thống miền đặc tính.

Nguyễn Đức Vinh, Nguyễn Công Thăng - Xử lý băng địa chấn bị nhiễu bằng phương pháp thống kê.

\section{Volume 12, Number 3 (1996)}

Đoàn Văn Ban - How much information of concurrency can be got from firing sequences in Petri nets.

Nguyễn Thanh Thủy - Hệ trợ giúp kê và kiểm tra đơn thuốc chữa bệnh tăng huyết áp ES Tension. 
Nguyễn Đức Vinh, Nguyễn Công Thăng - Tính lý thuyết trường sóng địa chấn trong vỉa than trên mô hình toán.

Lê Xuân Lam, Tống Đình Quỳ - Tối ưu hóa việc mở rộng quy mô và khai thác một hệ thống.

Vũ Ngọc Phàn - Điều khiển bền vững hệ MIMO với bất định đầu vào.

Đỗ Văn Thành - Tích hợp của các phân bố và toán tử tích hợp.

Phạm Hồng Hạnh, Valery Simonenko - Task assignment for scheduling jobs and resources in parallel distributed systems.

Hồ Thuần, Malki Mimoun - Quelques résultats additionnels sur les clés d'un schéma de relation.

Le Trong Luc - The inverse source problems for the Helmholtz operators.

\section{Volume 12, Number 4 (1996)}

Đỗ Văn Thành - Stability of the principles of minimal specificity and maximal Buoancy.

Lê Văn Cường, Trần Thành Trai, Nguyễn Kim Khôi - Về một bài toán tiết kiệm và tiêu dung với thời gian rời rạc.

Phan Chí Vân - Về một bài toán biểu diễn tri thức tự nhiên.

Vũ Ngọc Phàn - Nhận dạng các đối tượng mimo ổn định với giới hạn bất định cho trước.

Nguyễn Quang Hoan - Mở rộng cấu trúc và hàm Liapunov cho mạng nơron Hopfield.

Nguyễn Quý Hỷ, Lê Xuân Lam - Về một mô hình dự báo trong kế hoạch hóa việc huy động và 58 hoàn vốn đầu tư.

Nguyễn Thanh Thủy - Các kỹ thuật trợ giúp chứng minh bài toán hình học: cách tiếp cận trí tuệ nhân tạo.

Nguyễn Hải Châu - Thiết kế và cài đặt một thủ tục mạng.

Chu Văn Hỷ - Phương pháp thiết kế giá kỳ vọng cho hệ thống với thông số bất định.

Ho Thuan - Some more properties and remarks about keys for relation scheme.

Nguyễn Hồ Quỳnh, Nguyễn Trung Hòa - Về một thuật toán chặt khúc chuỗi thời gian thành các đoạn tự hồi quy $\operatorname{AR}(\mathrm{p})$.

Trương Đức Hùng, Lê Tiến Vương - Về một cách tiếp cận cơ sở dữ liệu thiếu thông tin.

\section{Volume 13, Number 1 (1997)}

Phí Mạnh Lợi - SCADA-NET mạng thông tin dữ liệu thời gian thực.

Nguyễn Bường - An iterative method for solution of nonlinear operator equation.

Vũ Đức Thi - On the nonkeys.

Trần Đình Khang - Xây dựng hàm đo trên đại sô gia tử và ứng dụng trong lập luận ngôn ngữ.

Phương Minh Nam - Tìm kiếm trong hệ cơ sở dữ liệu hệ latin.

Đỗ Văn Thành, Ngô Ánh Tuyết - Đề nghị một phương pháp xây dựng phần mềm dạy học.

Vũ Đức Thi - Some computational problems related to normal forms. 


\section{Volume 13, Number 2 (1997)}

Phí Mạnh Lợi - LNET - Hệ phần mềm xây dựng các mạng WAN và ứng dụng.

Vu Duc Thi - Some results about hypergraph.

S. Hoàng, R. Baraille, O.Talagrand, X.Carton, P.De Mey - On adaptive filtering for high dimentional systems under parameter uncertainty and its application to satellite data assimilation in oceanography.

Nguyễn Như Chương, Trần Đăng Điện - Nghiên cứu xây dựng nguyên lý thay thế thuốc phóng cho các loại đạn pháo hiện có.

Vũ Thanh Hà - Phương pháp đối ngẫu giải bài toán điều khiển tối ưu tuyến tính với dàng buộc dạng alternative.

Nguyễn Thanh Thủy, Nguyễn Hữu Đức - Thiết kế và cài đặt giao diện đồ họa trợ giúp học sinh vẽ hình phục vụ học sinh giải bài toán chứng minh hình học phẳng.

Phương Minh Nam - An ninh dữ liệu và an ninh các mạng LAN.

Vũ Như Lân, Vũ Chấn Hưng, Đặng Thành Phu - Điều khiển trên cơ sở lọc hai mức với mô hình nhiễu quan sát mở rộng.

\section{Volume 13, Number 3 (1997)}

Phan Dinh Dieu, Tran Dinh Que - From a convergence to a reasoning with internal-valued probability.

Hoàng Kiếm, Đỗ Văn Nhơn - Mạng tính toán và ứng dụng.

Nguyễn Hải Châu - Ứng dụng luật điều khiển mờ trong quá trình quyết định đường đi trên mạng.

Lê Hùng Lân - Phương pháp xây dựng miền ổn định robot.

Vũ Ngọc Phàn - Loại trừ nhiễu ngoại lai trên các hệ điều khiển nhiều đầu vào, nhiều đầu ra có chứa bất định.

Lê Xuân Quảng - Phương pháp gần đúng giải bài toán truyền sóng ứng dụng trong thăm dò địa chấn.

Trần Đình Khang - Tích hợp các đại số gia tử cho suy luận ngôn ngữ.

Chu Văn Hỷ - Thiết kế hệ thống điều khiển số tối ưu bền vững với phản hồi đầu ra.

Vu Duc Thi - Armstrong relations and strong dependencies.

Phạm Đức Thành - Tái sử dụng phần mềm trong tin học quản lý.

Petr Hajek, Nguyễn Hoàng Phương - Mobius transform for CADIAG-2.

Nguyễn Quang Thủy, Trương Minh Nhật Quang - Các giải pháp cho phần mềm chống virus thông minh.

\section{Volume 13, Number 4 (1997)}

Đoàn Văn Ban - Sử dụng phân tích hướng đối tượng để phát triển những hệ thống lớn tích hợp.

Vũ Ngọc Phàn - Các hệ thống tự động: bất định và điều khiển.

Đỗ Năng Toàn - Một phương pháp giữ các điểm khớp trong vectơ hóa bán tự động không qua làm mảnh.

Đặng Quang Á - Iterative methods for solving degenerate system of grid equations. 
Đặng Văn Đức, Lê Quốc Hưng, Trần Cẩm Ngân - Một phương pháp xác định vị trí hiển thị thông tin phi hình học trong hệ thống thông tin địa lý.

Nguyen Buong - On the stoppage rule in solution for monotone ill-posed problems.

Trần Văn Ngọc - Phần mềm thẩm định dự toán và quyết toán công trình xây dựng cơ bản.

Chu Văn Hỷ - Bộ điều khiển tối ưu bền vững cho hệ thống điều khiển số có trễ.

Nguyễn Trọng Toàn, Nguyễn Đức Nghĩa - Giải bài toán k-median nhờ quy hoạch lõm.

Phương Minh Nam, Lê Tiến Vương - Về giải thuật so sánh hai từ trong thuật toán truy nguyên đồng nhất.

Vu Duc Thi - On the hypergraphs and candidate keys.

Nguyễn Nam Hải, Phí Mạnh Lợi - Về một ứng dụng của vector time trong các hệ cơ sở dữ liệu phân tán.

\section{Volume 14, Number 1 (1998)}

Vũ Đức Thi - Some problems on the functional dependency related to Amstrong relation in the relational datamodel

Nguyễn Hoàng Phương - MMM-CADIAG: a mini modifield CADIAG with M bius transform

Vũ Ngọc Phàn - Phân tích ổn định bền vững của các hệ thống điều khiển IMC

Trần Ngọc Hà, Nguyễn Thanh Thủy - Mạng nơron nhiều lớp lan truyền ngược dùng cho việc mô hình hóa

Nguyen Trong Toan - A modification of tuy's algorithm for canonical DC programming problem

Chu Van Hy - Điều khiển thích nghi các hệ thống phi tuyến cấu trúc thay đổi sử dụng hệ thống mờ nơron

Tran Xuan Sinh - Một mở rộng bài toán "chiếc túi"

Le Quoc Hung - Một phương pháp xây dựng quan hệ thông tin không gian trong hệ thông tin địa lí véctơ phân cấp

Vu Nhu Lan - Mạng nơron nhiều lớp với thuật toán học trên cơ sở lọc siêu Kalman mở rộng

\section{Volume 14, Number 2 (1998)}

Vu Duc Thi - On the computational algorithm related to antikeys

Chu Van Hy - Điều khiển mờ thích nghi các hệ thống phi tuyến thời gian rời rạc

Trần Ngọc Hà, Nguyễn Thanh Thủy - Mạng nơron lan truyền ngược hướng cho nhận dạng ký tự

Ung Ngoc Quang - Về ước lượng Bayes của tham ẩn hỗn hợp trong mô hình hồi quy phi tuyến nhiều chiều

Vu Nhu Lan - Điều khiển tối ưu phi tuyến sử dụng mạng nơron

Ngo Hoang Huy, Ngo Quoc Tao - Recognizing some geometrical objects from a discrete set of polygons

Nguyen Thanh Thuy, Truong Minh Nhat Quang - Các cơ chế chuẩn đoán virut tin học thông minh dựa trên tri thức

Le Manh Thach - Lý thuyết điểm bất động trong cơ sở dữ liệu suy dẫn 


\section{Volume 14, Number 3 (1998)}

Vũ Ngọc Phàn - Thiết kế bộ điều khiển chung tối ưu theo chuẩn $H_{\infty}$ cho một lớp các đối tượng nhiều đầu vào, nhiều đầu ra (A common $H_{\infty}$ optimal controller for a collection of mimo plants)

Lê Bá Dũng, Nguyễn Việt Hương - Tổng quan về điều khiển mờ (The introduction of fuzzy control)

Vũ Đức Thi - Một số thuật toán tổ hợp liên quan đến siêu đồ thị (Some combinatorial algorithms connecting hypergraphs)

Đỗ Năng Toàn, Ngô Quốc Tạo - Kết hợp các phép toán hình thái học và làm mảnh để nâng cao chất lượng ảnh đường nét (Combining morphology operations and thinning technique for improving lines in images)

Nguyễn Bường - Về cách tiếp cận của Liskovets cho bài toán không chỉnh phi tuyến với toán tử nhiễu bất kỳ (On Liskovets approach for nonlinear ill-posed problems under arbitrarily perturbative operators )

Trần Đình Khang - Ứng dụng đại số gia tử đối sánh các giá trị ngôn ngữ (Using of hedge algebras for comparison of linguistic values)

Hồ Thuần, Lê Văn Bào, Hồ Cẩm Hà - Cấu trúc của phụ thuộc đa trị trong lược đồ quan hệ (Structure of multivalued dependencies in relation scheme)

Chu Văn Hỷ - Mạng nơron truyền thẳng cho điều khiển thích nghi các hệ thống phi tuyến (Feedforward neural networks to adaptive control of nonlinear systems)

Nguyễn Xuân Huy, Trịnh Đình Thắng - Mô hình cơ sở dữ liệu dạng khối (A database model of block form)

Phan Văn Từ - Mô phỏng một hệ động học phi tuyến, không dừng chịu tác động của nhiễu (The simulation model of dynamic nonlinear, time-variable system under acting of a noise)

\section{Volume 14, Number 4 (1998)}

Chu Văn Hỷ - Hệ thống mờ nơron với học cấu trúc trên cơ sở cộng hưởng thích nghi và ứng dụng trong điều khiển "đón đầu trước một bước" (A neural fuzzy system with art structure learning and its application in one step ahead control)

Phan Văn Từ - Tính toán quỹ đạo thiết bị bay không người lái (The calculating trajectory of nonpilot fly equipment)

Hồ Anh Minh, Huỳnh Văn Nam - Về toán tử tựa phần bù tương đối trong đại số gia tử mịn hóa hữu hạn (On the relatively pseudo-complement operation in finite RHAs)

Đoàn Văn Ban - Thuật toán tính tổng theo miền trong xử lý phân tích trực tuyến đối với các kho dữ liệu (The range-sum algorithm for OLAP data warehouse)

Đặng Huy Ruận, Phùng Văn Ổn - Độ phức tạp otomat hữu hạn đoán nhận siêu ngôn ngữ chính quy (On the complexity of a finite automaton recognizing regular hyper-languare)

Đào Thu Hòa - Phép kéo theo trên dàn con $X_{2}$ của dàn phân phối RHA (Implication operators on sublattice $X_{2}$ of refined hedge algebras)

Nguyễn Thanh Thủy, Nguyễn Hữu Đức, Nguyễn Vũ Quốc Hưng - Nâng cao hiệu quả suy diễn tự động trong bài toán chứng minh (Improving inference efficiency in automatic proof)

Phan Đinh Lợi, Nguyễn Thúc Hải - Tiếp cận hướng đối tượng cho hệ thống thông tin kho bạc nhà nước (The object-oriented approach for information system of the state treasury of Vietnam)

Vũ Đức Thi - Các mối liên hệ giữa quan hệ, sơ đồ quan hệ và khóa (On the connections between relations, relation schemes and keys) 
Đặng Quang Á - Phương pháp lặp giải bài toán biên thứ hai đối với phương trình loại song điều hòa (Iterative method for solving the second boundary value problem for biharmonic type equation)

Hồ Thuần, Trần Thiên Thành - Biểu diễn câu hỏi của SQL trong phép tính quan hệ (SQL query expressed in relational calculus)

\section{Volume 15, Number 1 (1999)}

Hoàng Xuân Huấn - Một số mô hình toán ứng dụng trong kinh tế - xã hội ở nước ta. (Some applied mathematical models on social-economic in Vietnam.)

Nguyễn Đức Nghĩa, Võ Văn Tuấn Dũng - Thuật toán đa thức giải một lớp bài toán tối ưu rời rạc. (Polynomial algorithm for solving a class of discrete optimization problems.)

Ung Ngọc Quang, Nguyễn Việt Long - Về ứng dụng của ngôn ngữ lập trình Mathematica programming to Markov chains.

Bùi Thi Thúy Hiền - Cơ sở dữ liệu quan hệ với giá trị null phụ thuộc vào ngữ cảnh. (Relational databases with context dependent null values.)

Nguyễn Thanh Thủy, Lê Hoàng Thái - Giải thuật di truyền: kỹ thuật và ứng dụng. (Genetic algorithm: technique and its application in data analysis.)

Thái Quang Vinh - Điều khiển PID hai mức với điều kiện hạn chế modan. (Two level PID controller with modan limitation.)

Phan Văn Từ - Giải bài toán điều khiển thiết bị bay không người lái trong mặt phẳng thẳng đứng. (The solution of control problem of nonpilot fly equipment in vertical plan.)

Hoàng Đình Dung - Lược đồ sai phân cho nghiệm suy rộng của một vài phườn trình vi phân loại ellip, I. (Difference schemes for generalized solutions of some elliptic differential equations, I.)

Vũ Đức Thi - Một số kết quả dạng chuẩn ba cho sơ đồ quan hệ. (Some rerults about the third normal form for relation schem.)

Trịnh Nhật Tiến - Thuật toán $O\left(n^{2} \cdot \log n\right)$ tạo lịch biểu không ngắt trên một máy. $\left(\operatorname{An} O\left(n^{2} \cdot \log n\right)\right.$ algorithm for a nonpreemtive schedule on one machine.)

\section{Volume 15, Number 2 (1999)}

Nguyễn Bường - Tốc độ hội tụ trong hiệu chỉnh phương trình với toán tử accretive. (Convergence rates in regularization for equations involving accretive operators.)

Trần Thái Sơn - Lập luận xấp xỉ với giá trị của biến ngôn ngữ. (Approximate reasoning with values of linguistic variable.)

Nguyễn Thanh Thủy, Trần Ngọc Hà - Tích hợp kỹ thuật mạng nơron và giải thuật di truyền trong phân tích dữ liệu. (Integration of neural network and genetic algorithms for data analysis.)

Đặng Huy Ruận, Phùng Văn Ổn - Cận dưới độ phức tạp otomat hữu hạn đoán nhận siêu ngôn ngữ chính quy. (The lower limits of the complexity of a finite automaton recognizing regular hyper-language.)

Vũ Đức Thi, Lê Hải Khôi - Một số nguyên lý hoạt động của kho dữ liệu. (Some essential principle of data warehouse.)

Vũ Duy Lợi - Công nghệ ATM và ứng dụng trong mạng cục bộ LAN. (ATM and its applications in local-area network LAN.)

Đỗ Năng Toàn - Ứng dụng chu tuyến vào việc loại bỏ đối tượng nhỏ trong quá trình vectơ hóa tự động. (Application of contouring to delete small objects in automatic vectorizing process.)

Bùi Thị Thúy Hiền - Mở rộng các phép toán quan hệ cho null phụ thuộc ngữ cảnh. (Extending relation operators for context dependent nulls.) 
Ngô Quốc Tạo - Nắn chỉnh hình học và gắn phép chiếu cho bản đồ trong nhập bản đồ tự động. (Geometrical correction and geo-referencing for automatic map data entry.)

Võ Văn Tuấn Dũng, Trần Vũ Thiệu - Phương pháp giải một lớp bài toán quy hoạch nguyên có cấu trúc đặc biệt. (Solving a class of integer problems with special structure.)

\section{Volume 15, Number 3 (1999)}

Đoàn Văn Ban - Một số tính chất của quá trình thừa kế kiểu trong mô hình cơ sở dữ liệu hướng đối tượng. (Some properties of inheritance process in object-oriented database model.)

Nguyễn Xuân Huy, Trịnh Đình Thắng - Một vài thuật toán cài đặt các phép toán của đại số quan hệ trong mô hình dữ liệu dạng khối. (Some algorithms realizing relational operators in the database model of block form.)

Chu Văn Hỷ - Tối ưu hóa sử dụng mạng nơron và ứng dụng trong điều khiển tự động. (Optimization using neural networks and applications in automatic control.)

Hoàng Kiếm, Lê Hoài Bắc, Lê Hoàng Thái - Mạng nơon và logic mờ: một ứng dụng trong nhận dạng vân tay. (Neural network and fuzzy logic: an application to fingerprint recognition.)

Bùi Thị Thúy Hiền - Ngữ nghĩa dữ liệu trong cơ sở dữ liệu quan hệ có giá trị null phụ thuộc ngữ cảnh. (Semantics of data in relational databases with context dependent null values.)

Nguyễn Thanh Thủy, Trương Minh Nhật Quang - Cây chỉ thị nhị phân biểu diễn không gian trạng thái chuẩn đoán vi rút tin học. (Binary instruction tree representing state space for diagnosing computer viruses)

Nguyễn Xuân Hào - Một số cải tiến trong quá trình xây dựng phủ tối thiểu. (Some improvements for finding a minimal cover.)

Vũ Ngọc Phàn - Thiết kế bộ điều khiển tối ưu theo chuẩn $H_{\infty}$ bằng cách sử dụng thuật di truyền. ( $H_{\infty}$ - optimal controller design using genetic algorithms.)

Nguyễn Đăng Khoa - Hệ trợ giúp quyết định phục vụ công tác bồi dưỡng và đào tạo công chức. (Applying the decision support system for training and upgrading public servants.)

Nguyễn Xuân Huy, Nguyễn Xuân Hoài - Xây dựng chương trình thiết kế ảnh fractal trực quan. (On a method of building a virtural design program for fractal images.)

Hà Đặng Cao Tùng - Liên hệ giữa nguyên lý entropy cực đại và giả thiết độc lập có điều kiện trong logic xác suất. (On the relation between maximum entropy principle and the condition independence assumption in the probabilistic logic.)

\section{Volume 15, Number 4 (1999)}

Nguyễn Bường - Về phương trình Hammerstein suy biến. (On singular Hammerstein equations.)

Nguyễn Nhụy, Phạm Quang Trình, Vũ Thị Hồng Thanh - Không gian Chu hữu hạn chiều. (Finite-dimentional Chu space.)

Nguyễn Hoài Nam - Ứng dụng thuật toán tự thích nghi gạt giao thoa trong kênh pha đinh lựa chọn. (Apply the adapted algorithm to interference cancellation in selective Fading chanel.)

Vũ Đức Thi - Một vài kết quả về quan hệ Armstrong cực tiểu đối với lược đồ quan hệ. (Some results related to the minimal Armstrong relation for relation scheme.)

Ngô Minh Khải, Hoàng Minh, Trương Nhữ Tuyên, Nguyễn Ngọc San - Nhận dạng hệ thống liên tục: khảo sát chọn lọc. Phần I. Tổng quan, những mô hình và phương pháp đánh giá. (Continuous time system identification: a selected critical survey. Part I. General view, some models and estimation methods.) 
Đỗ Đức Giáo, Lê Anh Cường - Tối ưu hóa cây nhị phân một chiều với thông tin chứa ở các đỉnh trong. (Optimazation for one dimension binary search trees with informations in nodes.)

Ngô Trần Anh - Phương pháp xây dựng công cụ tra cứu và tìm kiếm nhanh các trang Web trên Internet/ Intranet. (A method of design of fast seeking and searching untility for Web pages on Internet/ Intranet.)

Nguyễn Văn Tam, Nguyễn Thúy Hường, Ngô Trần Anh, Phạm Minh Vĩ - Hệ thống quản lý lưu trình công việc và bản tin trên mạng WAN. (System of workflow and news management for WAN.)

Lê Thế Sơn - Đồng nhất hóa các đường đặc tính uốn của cánh quay trực thăng dựa theo kết quả của phương pháp kiểm thử tần số. (Identification of elastic characteristics of helicopter's rotor blade by results of frequency test.)

\section{Volume 16, Number 1 (2000)}

Nguyễn Thụy Anh, Nguyễn Ngọc San - Tóm tắt về giảm bậc cho các mô hình: một giải pháp mang tính bình phẩm. (Brief on order-reduction for models: a critical survey)

Vũ Đức Thi, Lương Cao Sơn - Về dạng chuẩn Boyce-Cold của sơ đồ quan hệ (On the Boyce Codd normal form for relation scheme)

Trần Đình Quế - Về ngữ nghĩa của logic sắc xuất. (About semantics of probabilistic logic.)

Ngô Minh Khải, Hoàng Minh, Trương Nhữ Tuyên, Nguyễn Ngọc San - Nhận dạng hệ thống liên tục: khảo sát chọn lọc. Phần II. Phương pháp sai số đầu vào và phương trình quy chiếu tối ưu. (Continuous time system identification: a selected critical survey. Part II. Input error methods and optimal projection equations.)

Hồ Khánh Lâm - Tối ưu mạng máy tính theo độ tin cậy và chi phí. (Optimization the reliability and the cost of computer networks.)

Đỗ Năng Toàn - Một thuật toán phát hiện vùng và ứng dụng của nó trong quá trình véc tơ hóa tự động. (An algorithm to detect region and its implementation in automatic vectorizing process.)

Đỗ Văn Thành - Một cách tiếp cận ra quyết định trong chẩn đoán lâm sàng. (Approach for making decision in clinical diagnostics.)

Nguyễn Hữu Hậu - Xử lý tín hiệu băng rộng trong miền không gian bằng mạng các hàm cơ bản đói xứng xuyên tâm. (Broadband signal processing in space and time domain using radial basis function networks.)

Lê Ngọc Giao - Xây dưng phần mềm thiết kế mạng báo hiệu số 7. (Software tool for signaling network No. 7.)

Nguyễn Ngọc Kỷ - Phương pháp biểu diễn cấu trúc ký tự theo hướng tiếp cận véctơ. (Method of structural representation of characters using vectorisation.)

Vũ Như Lân, Vũ Chấn Hưng, Đặng Thành Phu - Ước lượng nhiều mức trạng thái hệ động lực tuyến tính mờ. (Multistep state estimation of the fuzzy linear dynamical systems.)

\section{Volume 16, Number 2 (2000)}

Lương Cao Sơn, Vũ Đức Thi - Một số khảo cứu về dạng chuẩn hai. (Some observations on the second normal form.)

Đặng Huy Ruận, Phùng Văn Ổn - Một số tính chất của lớp siêu ngôn ngữ phi ngữ cảnh. (Some properties of context free hyper-languages.)

Hoàng Đình Dung - Lược đồ sai phân cho nghiệm suy rộng của một vài phương trình vi phân loại ellip, II. (Difference schemes for generalized solutions of some elliptic differential equations, II.) 
Đặng Công Trạm, Chu Văn Hỷ - Lập lịch tối ưu cho bộ chuyển mạch ATM sử dụng mạng nơron. (Optima,l scheduling for asynchronous transfer mode switches using neural networks.)

Nguyễn Xuân Huy, Trịnh Mỹ Bình - Một thuật lập lịch biểu để điều khiển các giao tác theo mô hình đọc và đọc ghi. (An algorithm for scheduling a set of transactions in real and read-and-write model.)

Đoàn Văn Ban, Hồ Văn Hương - Các giải pháp kết nối web với cơ sở dữ liệu. (Solutions for linking web with databases.)

Vũ Chấn Hưng, Vũ Như Lân, Đặng Thành Phu - Điều khiển thích nghi hệ thống khí động học quạt gió-cánh nhôm. (Adaptive control of the fan-plate aerodynamic system.)

Nguyễn Thanh Thủy, Trương Minh Nhật Quang - Máy ảo, công cụ hõ trợ hệ chẩn đoán và diệt virus tin học thông minh. (Virtual machine - tool for diagnosing and destrying computer viruses.)

Phạm Quang Trung, Nguyễn Xuân Huy - Thuật toán tổng hợp lược đồ cơ sở dữ liệu quan hệ dạng chuẩn ba. (An algorithm for synthesizing a relational database scheme into third normal form.)

Ngô Tứ Thành - Hướng của điểm đặc trưng trên ảnh vân tay. (Orientation of the minutia on fingerprin image)

Lê Hải An - Mạng nơ ron trong xác định thạch học. (Neutral network in lithology determination.)

Nguyễn Hữu Hậu - Ưng dụng mạng RBF trong xử lý ảnh trải phổ. (Applying radial basis function networks in spread spectrum signal processing.)

Trần Vĩnh Phước - Quá trình xây dựng cơ sở dữ liệu nền trong các hệ thống thông tin địa lý (GIS) phục vụ quản lý hành chính cấp tỉnh. (A procedure for constructing a GIS basic data base for the public administration.)

\section{Volume 16, Number 3 (2000)}

Nguyễn Ngọc Kỷ - Dạng điểm và đối sánh dạng điểm-ứng dụng trong nhận dạng ký tự tiếng Việt. (Point pattern and application for recorgnition of Vietnamese characters.)

Đoàn Văn Ba - Tính đúng đắn của lược đồ cơ sở dữ liệu hướng đối tượng. (Correctness of objectoriented database schema.)

Vũ Ngọc Phàn - Ưng dụng thuật toán tiến hóa giải bài toán tối ưu đa mục tiêu. (Application of evolutionary algorithms to the multi-objective nonlinear optimization.)

Trần Thọ Châu - Lưới Petri mờ và một điều kiện cần đối với luật tương phản trong logic mờ. (Fuzzy Petri nets and a necessary condition of law of contraposition in fuzzy logic.)

Vũ Văn Hùng - Phương pháp sai phân giải xấp xỉ bài toán biến đổi với phương trình truyền nhiệt hệ số biến đổi (A difference method for approximately solving the boundary heat propagation problem with variable coefficients.)

Nguyễn Quốc Anh, Phạm Hồng Hạnh, Hồ Sỹ Lợi - Phân lớp và tránh xung đột trong bài toán lập kế hoặch với thông tin không đầy đủ. (Clustering and avoiding conflicts in planning with incomplete information.)

Đỗ Đức Giáo, Đặng Thị Nga, Vũ Lê Tú - Tối ưu hóa cây nhị phân một chiều với thông tin chứa ở các đỉnh trong trên tập khóa hữu hạn. (Optimization for one dimensional binary search tree in the finite set of keys.)

Đỗ Tấn Phong, Hồ Thuần, Hà Quang Thụy - Một độ đo lựa chọn thuộc tính. (A measure for attribute selection.)

Ngô Quốc Tạo, Đỗ Năng Toàn - Một số phương pháp nâng cao hiệu quả nhận dạng phiếu điều tra dạng dấu phục vụ cho thiết kế hệ nhập liệu tự động MarkRead. (Some methods improving efficiencies of the mark recognizing for designing automatic survey entry system MarkRead.) 
Vũ Đình Hòa - Độ phức tạp của một số vấn đề lịch biểu với công đoạn dương. (The complexity of some flow-shop schedules with positive task-times.)

\section{Volume 16, Number 4 (2000)}

Nguyễn Xuân Huy, Lê Đức Minh, Vũ Ngọc Loãn - Các ánh xạ đóng và dùng trong cơ sở dữ liệu. (Closed mappings and application in databases.)

Hồ Thuần, Hồ Cẩm Hà, Huỳnh Văn Nam - Tiên đề hóa các phụ thuộc đa trị mờ trong mô hình cơ sở dữ liệu mờ. (Axiomatisation of fuzzy rnultivalued dependencies in a fuzzy relational data model)

Vũ Minh Lộc - Về một phương pháp hỗ trợ quyết định chọn nghề cho học sinh phỏ thông trung học dưa trên suy diễn mờ. (On a method of decision support system for students in making- career choice, based on fuzzy easonmg.)

Trần Đình Khang - Một phương pháp giải bài toán suy diễn mờ tổng quát thông qua nội suy mờ và tích hợp mờ. (A method to solve the generalized fuzzy reasoning problems by using fuzzy interpolation and fuzzy aggregation.)

Nguyễn Bá Tường - Khóa và các dạng chuẩn trong các sơ đồ quan hệ. (The key and normal forms in relation scheme.)

Phan Chí Vân - Khái niệm sơ đồ, lược đồ đối xứng. Sự đẳng cấu giữa các lược đồ đối xứng. (The concepts of the fussy logical scheme and the logical symmetric scheme. The isomorphism between the logical symmetric schemes.)

Nguyễn Nhụy, Vũ Thị Hồng Thanh - Không gian Chu hữu hạn chiều, không gian fuzzy và định lý bất biến trò chơi. (Finite-dimensional Chu space, fuzzy space and the game invariance t lieorern.)

Bạch Hưng Khang, Đỗ Năng Toàn - Ủng dụng khoảng cách Hausdorff trong đánh giá chuyển đổi các biểu diễn raster và vector. (Applying Hausdorff distance for estimating conversion between raster and vector representations.)

Nguyễn Phương Hoàng, Nguyễn Thúc Hải - Xây dưng công cụ đánh giá hiệu năng mạng máy tính qua các tham số chất lượng dịch vụ. (Designing and implementing the toolkit of QoS parameter-based network performance evaluation.)

Lê Thanh Hương, Phạm Hồng Quang, Nguyễn Thanh Thủy - Một cách tiếp cận trong phân tích văn bản tiếng Việt. (An approach to construct a system for Vietn arne e text analysis.)

Lê Hải Khôi - Thuật toán tìm bao đóng của tập sự kiện và loại bỏ luật dư thừa của tập luật trong hệ luật của hệ chuyên gia. (Algorithms for finding closure of the facts SCL and removing redundant redundant rules of the rules set in the rule-based system of the expert system.)

\section{Volume 17, Number 1 (2001)}

Đặng Quang Á - Ngoại suy theo tham số như một phương pháp song song trong vật lý toán. (Parametric extrapolation as a parallel method in mathematical physics.)

Hoàng Đình Dung - Lược đồ sai phân của nghiệm một lớp phương trình vi phân ellip phi tuyến. (Difference schemes of generalized solutions for a class of elliptic non-linear differential equations.)

Nguyễn Bường - Một chú ý về hiệu chỉnh bằng toán tử tuyến tính. (A note on regularization by linear operators.)

Trịnh Nhật Tiến - Thuật toán nhanh để tìm thời gian biểu với số lượng tùy ý các công việc đúng hạn và thời gian xử lý ít nhất. (The fast algorithm for founding nonpreemptive schedule with some on-time jobs in minimal processing time.)

Vũ Đức Thi - Một vài kết quả về những quan hệ trong mô hình cơ sở dữ liệu. (Some results about relations in the relational datamodel.) 
Vũ Đức Nghĩa - Một vài kết quả về hàm chọn. (Some rerults about choice functions.)

Nguyến Đình Thuần - Thuật toán cập nhật lan truyền trong cơ sở dữ liệu nhiều bản sao. (An update propagation algorithm in replicated databases.)

Đỗ Trung Tá, Lê Văn Phùng, Lê Đắc Kiên - Bài toán định tuyến tối ưu trong mạng viễn thông Việt Nam. (The optimal routing problem in Vietnam telecommunication network.)

Nguyễn Thanh Thủy, Phan Dương Hiệu - Lập luận trong các hệ trí thức F-luật. (Reasoning knowledge systems on F-rules.)

Lê Hùng Lân, Nguyễn Văn Bang, Phạm Thị Thu Hương - Hệ trợ giúp chẩn đoán kỹ thuật động cơ ô tô. (The fuzzy system for technical diagnosis of automobile engines.)

Hoàng Chí Thành - Các thuật toán tìm dạng chuẩn của vết và vết đồng bộ. (Algorithms for finding the normal form of traces and synchronous traces.)

Đặng Công Trạm, Chu Văn Hỷ - Điều khiển luồng tối ưu sử dụng mô hình động cho mạng ATM. (Optimal flow control using dynamic models for asynchronous transfer mode networks.)

M. B. Abbott, Trương Tùng, Vũ Hồng Châu - Hydroinformatics và một số ứng dụng ở Việt Nam. (Hydroinformatics and some applications in Vietnam.)

Phạm Quang Trung - Một số vấn đề đối với phụ thuộc kết nối. (Some problems for join dependency and project-join normal form.)

\section{Volume 17, Number 2 (2001)}

Laszlo Keviczky, Phạm Huy Thỏa - Phương pháp ước lượng thông số hệ thống sử dụng hàm trung gian. (System parameter estimation methods using template functions.)

Hồ Thuần, Trần Thiên Thành - Phụ thuốc hàm và phụ thuộc đa trị trong cơ sở dữ liệu quan hệ mờ. (On functional dependencies and multivalued dependencies in fuzzy relational databases.)

Lê Hải Khôi - Thuật toán làm mịn tập luật và xây dựng hệ luật chính quy của hệ chuyên gia. (Algorithms for refining the rules set and building the regular rule-based system of the expert system.)

Trần Đình Quế - Lập luận xác xuất dựa vào các tầng của cơ sở tri thức. (Probabilistic reasoning based on layers of knowledge base.)

Nguyễn Nhụy - Mở rộng phạm trù các không gian mở hữu hạn chiều thành hệ đầy đủ. (Completion of the category of finite-dimensional fuzzy spaces.)

Nguyễn Văn Định - Độ phức tạp ô tô mát của lược đồ biến đổi ngôn ngữ có chứa các phép toán có bậc hạn chế. (The automata complexity of the language transformation schema that contains operations with restricted degree.)

Trần Cảnh - Xác định gradient của một hàm bằng phương pháp Monte-Carlo. (Evaluating gradient of a differentiable function by Monte-Carlo method.)

Vũ Đức Thi - Một số quan sát về sơ đồ quan hệ trong mô hình dữ liệu quan hệ. (Some observations on the relation schemes in the relational datamodel.)

Nguyễn Hải Châu - Một số phương pháp suy luận nội suy tuyến tính trên mô hình mờ đa điều kiện. (Some linear interpolative reasoning methods on multi-condition fuzzy models.)

Phạm Quang Trung - Một số vấn đề phủ dạng vành và các khái niệm liên quan. (Some problems for an anular cover and relation concepts.)

Trần Thị Phiến - Về một công cụ khai thác cơ sở dữ liệu Oracle-Discoverer. (On the Oracle Discoverer - a tool for exploiting database.)

Cao Đình Thi - Chuẩn hóa văn bản chữ Việt soạn thảo trong word. (Standardization of documents compiling in the Vietnamese fonts in microsoft word.) 
Hoàng Xuân Huấn, Nguyễn Việt Thắng - Một giải pháp tiến hóa cho bài toán thời khóa biểu. (An evolutionary solution for the Time-tabling problem.)

\section{Volume 17, Number 3 (2001)}

Vũ Ngọc Phàn - Các thuật toán tiến hóa và ứng dụng trong điều khiển tự động. (Evolutionary algorithms and application to automatic control.)

Lê Hải Khôi - Về mô hình heuristic trên cơ sở phương pháp tiệm cận nhân tố chắc chắn đối với hệ chuyên gia. (A heuristic model based on the certainty factor approach for the expert system.)

Đoàn Văn Ban, Hồ Văn Hương - Tính khả tuần tự của giao thức điều khiển tương tranh khóa hai pha trong cơ sở dữ liệu thời gian thực. (Serializability of two phase locking concurrency control protocol in real time database.)

Nguyễn Hải Châu - So sánh hiệu năng các phần mềm cài đặt giao thức MPICH, LAM/MPI và PVM trên cụm máy tính Linux qua mạng Fast Ethernet. (A comparative study on performance of MPICH, LAM/MPI and PVM on a Linux cluster over Fast Ethernet.)

Hồ Thuần, Hồ Cẩm Hà - Một cách tiếp cận mở rộng mô hình cơ sở dữ liệu quan hệ để xử lý thông tin không đầy đủ và các phụ thuộc dữ liệu. (An approach to extending the relational database model for handling incomplete information and data dependencies.)

Vũ Đức Thi - Về họ cực tiểu (On the minimal family.)

Nguyễn Văn Định - Về các lược đồ cơ sở dữ liệu omega phi chu trình. (On the desirability of omega-acyclic database schemes.)

Phạm Hạ Thủy - Thiết kế phần mềm kiểm toán trên nền hệ thống cơ sở dữ liệu của Kiểm toán Nhà nước. (Design the Auditing software which is base the database system of State Audit of Vietnam.)

Lê Quốc Hán - Ngôn ngữ nhóm Aben. (On Abellian group languages.)

Lê Thanh Thu Hà, Nguyễn Thị Lan Hương - Thuật toán bộ gạt hồi âm trong điều kiện tín hiệu vào yếu. (An algorithm using for the echo canceller.)

Đặng Xuân Hồng - Xây dựng một thuật toán cho chuẩn hóa quan hệ về dạng chuẩn 3 dựa trên dữ liệu. (An algorithm for normalizing a relation to the third normal form.)

Nguyễn Xuân Huy, Nguyễn Mậu Hân - Lập lịch tối ưu trong cơ sở dữ liệu song song. (Optimization schedule database.)

\section{Volume 17, Number 4 (2001)}

Hồ Thuần, Hồ Cẩm Hà - Đại số quan hệ và quan điểm sử dụng null value trên một mô hình cơ sở dữ liệu mở. (Relational algebra and a point of view for using null value in a fuzzy database model.)

Đoàn Văn Ban, Đàm Gia Mạnh, Nguyễn Thế Dũng, Nguyễn Xuân Huy - Về mối liên hệ giữa suy diễn phụ thuộc hàm và suy diễn logic. (On the relation between dependence inference and logic inference.)

Nguyễn Xuân Huy, Đàm Gia Mạnh, Vũ Thị Thanh Xuân, Kim Lan Hương - Về một lớp công thức suy diễn. (On a class of inference formulas.)

Vũ Như Lân, Vũ Chấn Hưng, Đặng Thành Phu, Bạch Đông Nam - Điều khiển hệ tuyến tính khoảng sử dụng logic mờ và nguyên lý tschs mô hình. (Control of the linear interval systems using fuzzy logic and principle of separation of the models.)

Nguyễn Trọng Toàn, Nguyễn Văn Tuấn - Về một thuật toán xấp xỉ ngoài cho bài toán quy hoặch dc dạng chính tắc. (On an outer approximation algorithm for the canonical DC progmamming problem.)

Vương Quang Khải, Nguyễn Thúc Hải - Công nghệ tác tử di động và ứng dụng thử nghiệm trong thương mại điện tử. (Mobile Agent technology and its application in e-commerce.) 
Dương Anh Đức, Trần Minh Triết, Lương Hàn Cơ - Phiên bản mở rộng 256/384/512-bit của phương pháp mã hóa Rijndael. (The 256/384/512-bit version of the Rijndael block cipher.)

Lê Hoài Bắc, Lê Hoàng Thái - Mạng nơ ron và giải thuật di truyền ứng dụng cho nhận dạng ký tự viết tay. (Neural network \& genetic algorithm in application to handwritten character recognition.)

Nguyễn Xuân Thái - Lược đồ quan hệ có một khóa duy nhất. (Relation scheme that has a unique key.)

Đặng Huy Ruận, Nguyễn Thế Bình - Lớp các ngôn ngữ được đón nhận bởi ôtômát đẩy xuống gồm năm thành phần. (The family of languages accepted by pushdown automata with 5-components.)

Nguyễn Công Định - Tổng hợp hệ thống điều khiển rời rạc điều chế hỗn hợp dựa trên phương pháp tôpô. (Topo method based synthesis of discrete control system with combined modulation.)

Hoàng Quang - Chuyển đổi mô hình thực thể - quan hệ thành mô hình hướng đối tượng. (Translation from entities-relationship model to object-oriented data model.)

Lê Mạnh Thạnh, Trương Công Tuấn - Phân tích một số phương pháp xử lý vòng lặp vô hạn trong quá trình ước lượng câu truy vấn đối với chương trình datalog. (Analysis of some methods to avoid infinite loops in the process of query evaluation for the datalog programs.)

\section{Volume 18, Number 1 (2002)}

Đặng Quang Á - Phương pháp ngoại suy theo tham số giải hệ phương trình đại số tuyến tính suy biến. (Parametric extrapolation method for degenerate system of linear algebraic equations.)

Hồ Thuần, Nguyễn Văn Định - Sự liên hệ giữa khái niệm xác định trực tiếp và các FD-đồ thị. (The relationship between direct determinastion and FD-graph.)

Bina Ramamurthy, Vũ Nghĩa, Vũ Đức Thi - Một số tính chất của các hàm chọn. (Some properties of choice functions.)

Nguyễn Xuân Huy, Nguyễn Mậu Hân - Thuật toán quy hoạch động cho bài toán lập lịch tối ưu. (Dynamic distrubution algorithm for optimization schedule problem on parallel databases.)

Trần Thái Sơn - Một cách tiếp cận giải bài toán lập luận với mô hình mờ trên cơ sở đại số gia tử. (A method for approximate reasoning of fuzzy model based on theory of Hedge Algebras.)

Lương Chi Mai, Đỗ Năng Toàn - Ứng dụng khoảng cách Hausdorff trong phân tích trang tài liệu. (Applying Hausdorff distance for page layout analysis.)

Vũ Như Lân, Vũ Chấn Hưng, Đặng Thành Phu - Nguyên lý tách mô hình với luật IF-THEN và ứng dụng trong điều khiển hệ phi tuyến. (Principle of the model separation with IF-THEN rule and its application for control of thenonlinear systems.)

Nguyễn Thanh Thủy, Phan Dương Hiệu - Nghiên cứu một số toán tử suy diễn đối với hệ tri thức F-luật. (About reasoning operators in knowledge systems of F-rules.)

Nguyễn Quốc Khánh - Điều khiển nghẽn cho mạng ATM. (Congestion control in ATM networks.)

Lê Hải Khôi, Trần Anh Thư - Về sự kết hợp nhiều luật cho cùng kết luận đối với hệ chuyên gia dựa trên nhân tố chắc chắn. (On the combination of similarly concluded rules for the expert system based on certainty factors.)

Lê Mạnh Thạnh, Trần Nguyên Phong - Một số phương pháp tiếp cận trong việc xác định ngữ nghĩa của cơ sở dữ liệu tuyến. (Some approaches that define semantics of deductive database.)

Vũ Trọng Quế - Cây sinh tố đoán nhận tính đồng dư, số nguyên tố và xác định độ phức tạp của nó. (Derived number graph tree making out the divisability, prime number and its complexity.)

Nguyễn Đình Việt - So sánh hiệu suất của các kế hoạch kiểm soát lỗi trong mạng truyền thông máy tính. (Performance comparison of error control schemes in computer communication networks.) 


\section{Volume 18, Number 2 (2002)}

Hồ Thuần, Trần Thiện Thành - Ohuj thuộc mờ với lượng tử ngôn ngữ. (Fuzzy functional dependencies with liguistic quantifiers.)

Trần Gia Lịch, Phạm Ngọc Vinh - Mô hình số trị dòng chảy hai chiều đứng phi thủy tĩnh. (Numerical model of non hydroststic vertical bi-dimentional flow.)

Hồ Thuần, Lê Mạnh Thạnh, Trương Công Tuấn - Phân tích một số phương pháp xử lý vòng lặp vô hạn trong quá trình ước lượng câu truy vấn đối với chương trình datalog. (Analysis of some methods to avoid infinite loops in the process of query valuation for the datalog proograms.)

Nguyễn Thị Hải Yến - Một phương pháp kiểm tra tính ngẫu nhiên của dãy nhị phân. (A method for test randomness of finite binary sequences.)

Lê Hùng Lân - Ổn định tuyệt đối mạng nơ ron mờ. (The absolute stability of fuzzy neural networks.)

Vũ Minh Lộc - Chỉ mức bao hàm mờ giữ các tập mờ lấy giá trị khoảng và ứng dụng trong suy diễn mờ. (An expression for measyring the degree of the truth of inclusion with interval-valued fuzzy sets and application to resoning based on fuzzy sets.)

Nguyễn Kim Anh - Đại số khối trên các cơ sở dữ liệu đa chiều. (Cube algebra on multidimentional database.)

Đỗ Trung Tuấn - Công nghệ cho phép thiết kế hệ trợ giúp quyết định. (Technology for designing Decision Support Systems.)

Nguyễn Bé, Nguyễn Kỳ Tài, Võ Thị Thu Sương, Trần Như Hồng - Nhận dạng tham số hệ động kết hợp chỉnh hóa. (Parameter identification of dynamical systems with regulaization.)

Bùi Công Cường - Nghiệm tập thể mờ và ứng dụng. (Fuzzy collective solution and its applications.)

Nguyễn Thị Kim Dung, Lê Văn Phùng - Dự báo nhu cầu vốn đầu tư và phương hướng chủ yếu thu hút và sử dụng các nguồn vốn đầu tư cho giáo dục đại học Việt Nam giai đoạn 2000-2009. (Forecast of investment demand and essential direction for attracting and using investment sources to Vietnam Hight education in phase of 2000-2020.)

Lươmg Hồng Khanh, Vũ Ngọc Phàn - Lý thuyết mạng hàng đợi và ứng dụng trong các hệ thống truyền tin. (Queuning network theory and its application to communication systems.)

Nguyễn Đình Việt - Những cải tiến và hiệu suất của giao thwusc TCP trên mạng có đường truyền không dây. (TCP enhancements and performance over networks with wireless links.)

\section{Volume 18, Number 3 (2002)}

Nguyễn Thị Thanh Huyền, Phan Trung Huy - Tiếp cận mờ trong một số thuật toán so mẫu. (Fuzzy approach for some string matching algorithms.)

Vũ Như Lân, Vũ Chấn Hưng, Đặng Thành Phu, Nguyễn Văn Châu - Điều khiển trong điều kiện bất định trên cơ sở logic mờ và khả năng sử dụng đại số gia tử trong các luật điều khiển. (Control with uncertainty problems on the basis of fuzzy logic and the use of the hedge algebras in the knowledge -based system control.)

Nguyễn Xuân Huy, Nguyễn Xuân Hoàng, Vũ Mạnh Xuân, Nguyễn Văn Tảo - Phụ thuộc Boole dương theo nhóm bộ. (Tuple grouping Boolean dependences.)

Vũ Đình Hòa, Đỗ Như An - Nhận biết chu trình dominating là NP dầy đủ. (Recognizing dominating cycles in NP-hard.)

Nguyễn Văn Định - Các lớp siêu đồ thị phi chu trình và các thuật toán đoán nhận chúng. (Acyclic Hypergraphs classes and Algorithms for their recognition.)

Nguyễn Cát Hồ, Trần Thái Sơn, Trần Đình Khang, Lê Xuân Việt - Độ đo tính mờ, ánh xạ ngữ nghĩa định lượng và ứng dụng phương pháp lập luận xấp xỉ nội suy trong một hệ chuyên 
gia y tế. (Fuzziness Measure, Quantified Sematic Mapping and Interpolative Method of Approximate Reasoning in Medical Expert Systems.)

Phan Trung Huy, Vũ Thành Nam - Một số đặc trưng nhập nhằng của mã. (Some ambiguous properties concerning codes.)

Ngô Quốc Tạo, Phạm Việt Bình - Đơn giản hóa chu tuyến của các ngôi nhà. (Simplification of the contours of houses.)

Trần Duy Hưng, Nguyễn Ngọc Cương - Nhận dạng tự động ngôn ngữ tiếng Anh. (Automatic language recognition of written english.)

Nguyễn Công Phúc, Doãn Hồ Liên, Cao Văn Viên, Cù Thu Thủy - Ưng dụng thuật toán phân tích biệt số tuyến tính bằng giải thuật di truyền để tiến hành giải bài toán phân lớp trong $\mathrm{y}$ học. (Using linear discriminant analysis method based on genetic algorithms to solve the classifying problem in medical field.)

Phan Thị Tươi - Cải tiến một số giải thuật phân tích cú pháp trong xử lý ngôn ngữ tự nhiên. (Improvement of some parsing algorithms in natural language processing.)

Nguyễn Hoàng Sơn, Nguyễn Việt Hùng - Một số kết quả về khóa của sơ đồ quan hệ. (Translation of relation schemes.)

Bina Ramamurthy, Vũ Nghĩa, Vũ Đức Thi - Về tích trực tiếp của các hàm chọn. (On the direct product of choice function.)

\section{Volume 18, Number 4 (2002)}

Đỗ Đức Giáo, Phạm Ngọc Hùng, Đỗ Việt Hùng - Thuật toán phân rã lớp thông tin có cấu trúc dạng cây nhị phân chứa đỉnh trong trên taajpkhoas vô hạn. (The structured information composition algorithm for the infinite set of keys of binary search trees in node.)

Nguyễn Đăng Khoa - Cách tiếp cận tập thô trong việc phát hiện tri thức trong cơ sở dữ liệu. (Rough sets approach in knowledge data base discovery.)

Hoàng Trung Hải, Trần Hồng Quân - Dự báo phát triển dịch vụ viễn thông bằng mạng nơ ron. (The forecasting of the telecommunications service based on neural network.)

Bùi Thế Hồng - Về các thuật toán xây dựng cây quyết định và rút gọn tập luật. (On algorithms for decision tree construction and reduction of rule sets.)

Lương Hồng Khánh, Vũ Ngọc Phàn - Cực tiểu hóa thời gian trễ trung bình trong một mạng hàng đợi bằng giải thuật di truyền. (Minimizing the overage delay time in a queueing network by using genetic algorithms.)

Nguyễn Đình Việt - Mô phỏng sự định giá hiệu xuất của kế hoạch Snoop TCP đối với mạng không dây. (Simulation-based evaluation of performance of a Snoop TCP scheme over network with wireless links.)

Vũ Ba Đình, Nguyễn Xuân Huy, Đào Thanh Tĩnh - Đánh giá khả năng giấu dữ liệu trong bản đồ số. (On an estimate ability for information hiding in digital map.)

Nguyễn Cát Hồ, Lê Xuân Vinh - Vấn đề tiên hóa cho đại số gia tử không thuần nhất. (An axiomatization for non-homogeneueous hedge algebras.)

Chu Văn Hỷ, Phạm Bắc Việt - Ưng dụng luật điều khiển tối ưu bình phương tối thiểu cho điều khiển ngẽn trong mạng ATM. (Án application of the quadratic optimal control law to the congestion control in ATM networks.)

Nguyễn Kỳ Tài - Nhận dạng tham số hệ động phi tuyến kết hợp chỉnh hóa. (Identifying the arguments of dynamic non-linear system with regularization.)

Đoàn Văn Ban, Doãn Ngọc Liên, Hoàng Quang - Một số vấn đề trong mô hình hóa hệ thống phần mềm hướng đối tượng. (Some problems on object-oriented software system modeling.) 
Phan Hưu Phong - Ứng dụng lọc Kalman cho ước lượng lưu lượng trong mạng ATM. (An application of the Kalman filter for estimating the trafic in ATM networks.)

Đỗ Trung Tuấn - Mô hình khái niêm đa phương tiện. (The multimedia conceptual model.)

Volume 19, Number 1 (2003)

Đặng Huy Ruận - Ôtômát hữu hạn hai phía. (A doubleside finite automate.)

Nguyễn Quý Khang - Phương pháp lắc balô và thuật toán xấp xỉ dây con chung dài nhất. (Knapsack shaking method and approximate algorithms for LCS problem.)

Trần Thiên Thành - Một số mở rộng tổng kết dữ liệu trên cơ sở dữ liệu quan hệ mờ. (Some extensions of Data summaries on Fuzzy Relational Databases.)

Trần Đình Khang, Đinh Khắc Dũng - Suy diễn với tập mờ loại hai dựa trên đại số gia tử. (Fuzzy Resoning with type-2 Hedge Algebra based Fuzzy Sets.)

Võ Thanh Tú, Nguyễn Trung Hiếu - Xây dựng công cụ đánh giá độ tin cậy cho mạng nội bộ. (Developing the toolkit reliable evaluation for LAN)

Hoàng Quang - Một phương pháp chuyển đổi mô hình dữ liệu quan hệ thành mô hình dữ liệu hướng đối tượng. (A method for translation from relational data model to object-oriented data model.)

Nguyễn Cát Hồ, Nguyễn Văn Long - Làm đầy đủ đại số gia tử trên cơ sở bổ sung các phần tử giới hạn. (Complete hedge algebras based on limit-elements.)

Nguyễn Thị Hải Yến - Về tiêu chuẩn đại hàm nhị phân kiểm tra tính ngẫu nhiên của một dãy nhị phân hữu hạn. (Standard binary derivative complexity for the test randomness of finite binary sequence.)

Hồ Văn Hương - Đặc tả hình thức giao thức điều khiển tương tranh hướng hủy bỏ cho cơ sở dữ liệu thời gian thực trong logic tính toán khoảng. (A normal specification of the abort-oriented concurency control for real-time database in duration calculus.)

Hoàng Đình Dũng, Vũ Thế Ngọc - Lược đồ sai phân của nghiệm yếu bài toán hỗn hợp cho một lớp phương trình loại parabol I. (Difference schemes for weak solutions of mixed problem for a class of parabolic differential equations, I.)

\section{Volume 19, Number 2 (2003)}

Lê Quốc Hán, Nguyễn Thị Bích - Ngôn ngữ nhóm cô lập. (On Isolate - Languages having a groups as syntatic monoid.)

Lê Thành Lân - Toán đồ để lập 64 trùng quái. (Hexagrams by the mathematical graph of congruence.)

Nguyễn Văn Tam, Phạm Minh Vĩ, Phạm Thanh Giang - Xây dựng hệ thống theo dõi và điều khiển các máy tính trên mạng Internet/Intranet dựa trên giao thức SNMP. (Developing a system for monitoring and control of computers on Internet/Intranet with SNMP.)

Nguyễn Kim Anh - Chuẩn hóa sơ đồ cơ sở dữ liệu hướng đối tượng. (Object-oriented database schema normalization.)

Đặng Ngọc Đức, Lương Chi Mai - Nhận dạng từ có thanh điệu khác nhau trong tiếng Việt. (Recognition of vietnamese words with different tones.)

Nguyễn Mạnh Hùng, Phạm Văn Đương, Nguyễn Ngọc San - Phân tích các yếu tố ảnh hưởng đến quá trình hội tụ của thuật toán biến đổi gen. (Analyzing factors to convergence of genetic algorithm.)

Cao Đình Thi - Xây dựng phương pháp mã hóa để sắp xếp dữ liệu chữ Việt. (Contructing some coding methods to solf the data in Vietnamese.) 
Lương Hồng Khanh, Phùng Văn Vận - Điều khiển chấp nhận kết nối có ưu tiên cho mạng đa dịch vụ. (Connection administration control with priorities for multiservice networks.)

Nguyễn Bội Hồng Minh - Giao thức secure sockets layer. (Secure sockets layer protocol.)

Lê Hoài Anh - Phần mềm điều khiển máy rút tiền tự động. (The piloting software of ATM (Automatic Teller Machine).)

Nguyễn Quốc Khánh, Nguyễn Tất Đắc - Định tuyến tối ưu cho mạng ATM. (Optimal routing for ATM networks.)

Phan Trung Huy, Nguyễn Quý Khang - Ngôn ngữ chính quy từ vô hạn và vị nhóm hữu hạn có tích vô hạn. (Regular omega-languages and finite monoids having infinite products.)

Nguyễn Bường - Phương trình phi tuyến loại Hammerstein. (Nonlinear equations of Hammerstain type.)

\section{Volume 19, Number 3 (2003)}

Đỗ Năng Toàn - Nâng cao hiệu quả thuật toán trích chọn xương không qua làm mảnh. (Improving efficiency of skeleton algorithms without thinning process.)

Trần Thọ Châu - Một số đặc trưng của lý thuyết mô hình tính toán được tổng quát hóa trên số thực và các cấu trúc đại số khác. (Some characterizations of computation and complexity over the real numbers and other algebraic structures.)

Hoàng Đình Dung, Trần Xuân Bộ - Lược đồ sai phân cho nghiệm yếu bài toán hỗn hợp của một lớp phương trình Hyperboloc I. (Defference schemes for weak solutions of mixed problem for a class of hyperbolic differential equations I.)

Trần Hồng Quân, Phan Hữu Phong - Điều khiển lưu lượng động mạng ISDN băng rộng. (The dynamic traffic control method for B-ISDN network.)

Lê Mạnh Thạnh, Trương Công Tuấn - Tối ưu hóa câu truy vấn trong cơ sở dữ liệu suy diễn bằng phép biến đổi ma tập. (Query optimization in deductive databases by magic-sets transformation.)

Lê Hải Khôi, Đặng Xuân Hồng - Về mô hình Heurestic dựa trên tiếp cận chuẩn tam giác đối với hệ chuyên gia. (A heuristic model based on the triangular norms approach for expert systems.)

Nguyễn Thanh Thủy, Trinh Kim Chi, Phan Thanh Sơn - Khảo sát các đặc tính của hệ tri thức F-luật đơn điệu yếu. (Investigations in weakly monotic F-rule systems.)

Đoàn Văn Ban, Hồ Văn Hương - Đặc tả hình thức các điều kiện đúng cho thực hiện song song của hệ thống giao tác trong cơ sở dữ liệu thời gian thực. (A formal specification of the correctness criteria for concurrent executions of a transaction system in real time databases.)

Nguyễn Văn Long, Nguyễn Cát Hồ - Đại số gia tử đầy đủ tuyến tính. (Linear, complete hedge algebras.)

Ngô Đông Hải - Các bài toán tối ưu hóa trong mạng viễn thông: Nghiên cứu phân loại. (Optimization problems in telecommunication networks: A classification study.)

Đinh Minh Sơn - Điều khiển lưu lượng trong mạng ATM. (Trafic control in ATM networks.)

\section{Volume 19, Number 4 (2003)}

Phạm Thùy Phong - Phát hiện và nhận dạng sự cố trong mạng quản lý viễn thông. (Fault management of telecommunication management network (TMN).)

Trần Vĩnh Phước, Lưu Đình Hiệp - Mô hình biểu diễn đối tượng không gian dựa trên lý thuyết tập mờ và biến ngôn ngữ. (The model representing the spatial objects based on the fuzzy theory and linguistic variable.) 
Trần Đình Khang, Đinh Khắc Dũng - Xây dựng phép giảm loại tổng quát cho tập mờ loại 2. (Contructing the generalized type-reduction for type 2 fuzzy sets.)

Đặng Huy Ruận, Bùi Vũ Anh - Hàm grundy và ứng dụng trong lý thuyết trò chơi. (Hàm grundy và ứng dụng trong lý thuyết trò chơi.)

Trần Thiên Thành - Một số tính toán cho tổng kết dữ liệu trên cơ sở dữ liệu quan hệ mờ. (Some computations of data summaries on fuzzy relational databases.)

Đoàn Phan Long, Nguyễn Ngọc San - Nhận dạng thanh diệu tiếng Việt. (Vietnamese tone identification.)

Nguyễn Đăng Khoa - Cơ sở dữ liệu quan hệ thô và vấn đề tối ưu hóa câu hỏi. (Rough relational database and query optimization techniques.)

Hồ Thuần, Hoàng Thị Lan Giao - Mở rộng một số toán tử quan hệ lên cơ sở dữ liệu thiếu thông tin. (Discuss with properties a P.F. should posses and what constitutes a resonable extension of an operator relative to a given P. E.)

Nguyễn Xuân Huy, Vũ Thiện Căn - Các toán tử lai ghép cho thuật toán di truyền giải bài toán tô màu đồ thị đơn. (The crossover operators for the genetic algorithm in the problem of simple graph coloring.)

Nguyễn Cát Hồ, Lê Xuân Vinh - Về một số tính chất của quan hệ thứ tự trong đại số gia tử không thuần nhất. (On some properties of ordering relation in non-homogeneous hedge algebras.)

Lê Văn Sơn, Nguyễn Quang Thanh - Mô hình hóa hệ thống truy vấn cơ sở dữ liệu phục vụ sản xuất, kinh doanh qua mạng điện thoại công cộng. (Optimization problems in telecommunication networks: A classification study.)

Nguyễn Khắc Lịnh, Lê Hữu Lập - Giao thức hợp thức cho quản lý giao tác phân tán di động. (The commit protocol for mobile distributed transaction management.)

\section{Volume 20, Number 1 (2004)}

Nguyễn Hoàng Linh - Cân bằng kênh thích nghi. (Adaptive Chanel equalization.)

Trần Văn Lăng, Nguyễn Hoàng Anh - Thuật giải di truyền song song cho bài toán thiết kế mạch tổ hợp trên nhóm máy tính mạng. (Parallel genetic algorithm for solving the combinational logic circuit design problem on supercluster.)

Nguyễn Gia Hiểu, Võ Thanh Tú - Phân tích các tham số thông lượng và độ trễ trong đánh giá hiệu năng để thiết kế mạng Internet. (Analysis on performance evaluation with throughput and delay parameters for design of Internet.)

Lê Hải Khôi, Lê Quý Sơn - Về mô hình heuristic dựa trên tiếp cận lan truyền có cận đối với hệ chuyên gia. (A heuristic-model based on the bounds propagation approach for expert systems.)

Bùi Công Cường, Lê Bá Long - Độ đo không cộng tính, tích phân choquet và ứng dụng. (Nonadditive measures, the Choquet integrals and applications.)

Nguyễn Kỳ Tài - Thuật toán đánh giá bền vững Levenberg-Marquardt trong vấn đề khử tiếng vọng âm học. (Robust-estimation Levenberg-Marquardt algorithm in acoustic echo cancellation.)

Nguyễn Hồng Sơn - Điều khiển các hệ thống có trễ. (Control of systems with delays.)

Nguyễn Văn Long, Nguyễn Cát Hồ - Cơ sở toán học của độ đo tính mờ của thông tin ngôn ngữ. (Basic properties of fuzziness degrees for linguistic hedge.)

Ngô Đông Hải - Mã hóa kênh, nhìn từ quan điểm của lý thuyết hệ thống. (Channel coding from the point of view of system theory.)

Nguyễn Đình Thuần - Thuật toán khai thác dữ liệu tăng trưởng trong cơ sở dữ liệu có tính thời gian. (Algorithm for incremental data mining in temporal database.) 
Nguyễn Đăng Khoa, Vũ Huy Hoàng - Phụ thuộc hàm suy rộng trên cơ sở lý thuyết tập thô. (The generalized functional dependencies based on rough sets theory.)

\section{Volume 20, Number 2 (2004)}

Nguyễn Kỳ Tài - Bộ cân bằng -cân bằng mũ trong hệ phi tuyến và song tuyến. (The nonblind and blind equalizers for bilinear and nonlinear systems.)

Nguyễn Ngọc Khai, Đồng Sĩ Thiên Châu, Nguyễn Văn Mai, Trần Thị Hoàng Oanh - Về một phương pháp đánh giá thích nghi tín hiệu sinuoid. (An adaptive algorithm proposed to estimate sinusoidal signals.)

Lê Hải Khôi, Trần Đức Minh - Về một phương pháp dự báo dữ liệu sử dụng mạng nơ ron. (About a method to forecast using neural networks.)

Phan Xuan Hieu, Hà Quang Thụy - Khai phá song song luật kết hợp mờ. (Parallel mining for fuzzy association rules.)

Đào Văn Tuyết, Trần Văn Lăng - Mô hình đa thức tác tử và ứng dụng vào bài toán dự báo. (Multiagent model and predictive problem solving.)

Vũ Như Lân, Vũ Chấn Hưng, Đặng Thành Phu, Hoàng Hồng Sơn - Phương pháp liên hiệp mờ. (Fuzzy adjoint equations.)

Nguyễn Phạm Anh Dũng - Xây dựng phần mềm mô phỏng kênh vô tuyến di động phading. (Building Solfware for Simulating Fading mObile Radio Channel in mobile Telecommunications.)

Chu Văn Hỷ, Nguyễn Hồng Sơn - Bộ điều khiển gáo rò mờ thích nghi. (An adaptive fuzzy leaky bucket controller.)

Nguyễn Đình Thuân - Một số vấn đề truy vấn và cập nhật trong cơ sở dữ liệu có tính thời gian. (Some problems for query and update in temporal databases.)

Nguyễn Hoàng Linh - Một thuật toán tạo tia thích nghi cho dàn anten. (An adaptive beamforming for antenna arrays.)

Phùng Văn Ổn - Độ phức tạp đoán nhận lớp siêu ngôn ngữ chính quy sinh bởi siêu sơ đồ sinh suy rộng. (On the complexity of recognition of regular layer languages generating by extended hyper generating-schemas.)

Nguyễn Thanh Hải, Phạm Đạo - Điều khiển công xuất dự đoán cho hệ thống thông tin di động DS-CDMA. (Power control for mobile DS-CDMA systems.)

Volume 20, Number 3 (2004)

Hareton Leung, Hoang Phuong, Tran Ngoc Cuong, Le Hai Khoi - Một tiếp cận nhằm cải tiến phương pháp kiểm tra theo vùng. (An approach to improve the partition testing.)

Pham Tran Nhu, Nguyen Van Truong - Thiết kế hệ thống điều khiển thang máy. (Designing a lift control system.)

Vũ Ngọc Phàn - Một vài câu hỏi gợi mở của lý thuyết điều khiển. (Some issues challenging the control theory.)

Đổng Sĩ Thiên Châu, Trần Thị Hoàng Oanh, Nguyễn Ngọc Khai, Nguyễn Hoàng Minh - Mạng nơ ron nhân tạo, các thuật toán thích nghi bền vững và ứng dụng. (The artificial neural networks - robust adaptive algorithms and applications.)

Phạm Hồng Liên, Nguyễn Hoàng Minh, Nguyễn Kỳ Tài - Đánh giá bền vững các thông số của bộ lọc thích nghi trong thông tin vô tuyến. (Robust estimate of parameters of adaptive filters in wireless communication.)

Vũ Như Lân, Vũ Chấn Hưng, Đặng Thành Phu - Nhận dạng tham số mô hình hồi quy tuyến tính mờ sử dụng kỹ thuật liên hợp. (Parameter identification of fuzzy linear regression models using adjoint technique.) 
Lê Xuân Vinh - Về infimum, supremum của các cặp phần tử không sánh được trong đại số gia tử không thuần nhất. (On the supremum, infimum of two incomparable elements of non-homogeneous hedge algebras.)

Đoàn Văn Ban, Lê Mạnh Thạnh, Hoàng Bảo Hùng - Sự tương đương trong biểu diễn giữa ngôn ngữ truy vấn OQL và đại số đối tượng. (The equivalent expression between the OODB query language OQL and the object algebra.)

Lê Thành Lân - Kỹ thuật lập bảng và đồ thị bốn thông số. (Technique for establish the table and the graph of four parameters.)

Nguyễn Thúc Hải, Võ Thanh Tú - Sử dụng giải pháp tích hợp các cơ chế quản lý hàng đợi và báo nhận để tránh tắc nghẽn trên mạng Internet. (Congestion avoidance in the internet by integrating mechanism of queue and acknowledgement control.)

\section{Volume 20, Number 4 (2004)}

Phan Thị Thanh Nam, Bùi Quang Minh, Hà Quang Thụy - Giải pháp tìm kiếm trang web tương tự trong máy tìm kiếm Vietseek. (A searching solution for text-based similar pages in the Vietseek search engine.)

Lê Thanh, Nguyễn Thúc Hải - Phát triển giao thức xác thực kiểu Kerberos kết hợp kiểm soát truy nhập dựa trên vai hệ thống quản lý tài nguyên. (Developping Kerberos-role authentication protocol for resource management system.)

Phan Huy Khánh, Võ Trung Hùng - Nhận biết ngôn ngữ và bộ mã sử dụng trong các văn bản đa ngữ. (Automatical identification of any languages and coding systems used in heterogeneous.)

Nguyễn Hòa, Cao Hoàng Trụ - Cơ sở đối tượng sắc xuất mờ và phép chọn. (Fuzzy-probabilistic object bases and the selection operation.)

Lê Quốc Hán, Hồ Tiến Dương - Ngôn ngữ nhóm Duybrây và ngôn ngữ nhóm Kroazô. (On Croisot-languages and Dubreil-languages having a group as syntactic monoid.)

Vũ Như Lân, Vũ Chấn Hưng, Đặng Thành Phu - Ước lượng mờ trạng thái hệ thống phi tuyến. (Fuzzy state nonlinear system estimation.)

Lê Xuân Vinh - Một phương pháp lập luận ngôn ngữ dựa trên đại số gia tử không thuần nhất. (A method in linguistic approximate reasoning bases on Non-homogeneous hedge algebras.)

Nguyen Hoang Son - Chuyển dịch sơ đồ quan hệ và một số vấn đề liên quan. (Translation of relation schemes and some related problems.)

Lê Hải Khôi, Đặng Xuân Hồng, Nguyễn Lương Đống - Một số vấn đề xung quanh chuẩn tam giác Acsimet. (Some problems about Archimedean Triangular norms.)

\section{Volume 21, Number 1 (2005)}

Phạm Thượng Cát - Hệ thống nhứng và sự phát triển của công nghệ thông tin.

Trần Đình Khang, Đinh Khắc Dũng - Về quan hệ giữa tập mờ loại hai dựa trên đại số gia tử với một dạng tập mờ loại hai khác.

Vũ Như Lân, Vũ Chấn Hưng, Đặng Thành Phu, Nguyễn Duy Minh - Điều khiển sử dụng đại số gia tử.

Nguyễn Lãm, Lý Quốc Ngọc - Phân tích dữ liệu video số dựa trên mô hình phân cấp dữ liệu.

Đỗ Năng Toàn, Lương Chi Mai - Phân tích trang văn bản dựa vào mẫu.

Phương Minh Nam - Thiết kế và cài đặt một hệ xử lý vân tay.

Lê Tiến Thường, Trần Tiến Đức - Nhận dạng thanh điệu tiếng nói tiếng việt bằng mạng nơ ron phân tầng. 
Hoàng Chí Thành, Phạm Xuân Đồng - Bài toán điều khiển trên các hệ điều kiện-biến cố có tính thời gian.

Nguyễn Hoài Bão - Một vài mô hình hồi quy ngắn hạn lạm phát.

Volume 21, Number 2 (2005)

Bùi Minh Trí, Nguyễn Như Hạnh - Bài toán lập lịch trong các trường đại học và thuật toán Tabu. (The TimeTableting problem in universities and tabu method.)

Hoàng Kiếm, Nguyễn Thanh Hùng - Meta-heuristic kết hợp tuật toán giải di truyền với thông tin thống kê xác xuất giải quyết bài toán người đi du lịch. (Meta-heuristic combining genetics algorithm and statistical probality to solve traveling salesman problem.)

Lê Hải Khôi, Lê Quý Sơn - Một số đánh giá trong cơ chế suy diễn của mô hình heuristic với lan truyền có cận. (Estimation on inference of heuristic model with bounds propagation approach.)

Vũ Đức Thi, Nguyễn Hoàng Sơn - Mô tả khóa tối tiểu bằng họ trù mật của quan hệ trong cơ sở dữ liệu. (Desribing minimal keys by dense families of database relations.)

Đổng Sĩ Thiên Châu, Trần Thị Hoàng Oanh - Về một phương pháp nhận dạng bền vững bộ lọc phi tuyến dùng mạng nơ ron. (A robust identification method for nonlinear filters using neural networks.)

Nguyễn Thanh Thủy, Vũ Mạnh Xuân - Cơ cấu lựa chọn thích nghi toán tử lai ghép trong giải thuật di truyền mã hóa số thực. (Adaptive mechanism of selecting crossover operators in real-code genetic algorithms.)

Đặng Thanh Hải, Nguyễn Hương Giang, Hà Quang Thụy - Thuật toán phân lớp Bayes và vấn đề xác định ngưỡng phân lớp trong máy tìm kiếm. (A bayes classification algorithm and the problem to determine the classification threshold for search engine.)

Trần Ngọc Tuấn, Phan Thị Tươi - Văn phạm nét và tiếp cận ngữ nghĩa trong xử lý ngôn ngữ tự nhiên tiếng Việt. (Feature-Based Grammar in Adaptation to Vietnamese Natural Language Processing.)

Nguyễn Xuân Huy, Lê Quốc Hưng - Hai thuật toán tính diện tích và thể tích trong hệ thông tin địa lý. (Two algorithm of calculating area and volume in GIS.)

Phạm Huy Điển, Đinh Hưuu Toàn - Một giải pháp triển khai mô hình ký văn bản điện tử. (A practical implementation of a digital signature scheme.)

\section{Volume 21, Number 3 (2005)}

Vũ Như Lân, Vũ Chấn Hưng, Đặng Thành Phu, Lê Xuân Việt, Nguyễn Duy Minh Điều khiển mô hình máy bay hạ cánh sử dụng đại số gia tử AND=MIN. (Aircraft landing control problem using hedge algebra the case AND = MIN.)

Le Huu Lap, Nguyen Hong Son - Khả năng sử dụng token bucket để hủy hay đánh dấu gói tại core router trong các mạng IP. (Meta-heuristic- combining genetics algorithm and statistical probability to solve traveling salesman problem.)

Tran Duc Minh, Le Hai Khoi, Junzo Watada, Teruyuki Watanable - Một mô hình metacontrolled boltzman machine sửa đổi. (A modified meta-controlled boltzmann machine.)

Đặng Quang Á, Vũ Vinh Quang - Nghiên cứu thực nghiệm một phương pháp chia miền giải các bài toán với điều kiện biên hỗn hợp trong miền hình học phức tạp. (Experimental study of a domain decomposition method for solving mixed boundary value problems in domains of complicated geometry.)

Lê Thanh, Nguyễn Văn Ngọc, Nguyễn Thúc Hải - Phân cấp vai trong mô hình kiểm soát truy nhập dựa trên vai với rằng buộc thời gian. (Role hierarchies for temporal constraint role-based access control model.) 
Trần Thị Hoài Oanh, Đặng Sĩ Thiên Châu - Nhận dạnh mù chuỗi Hamerstaein bậc hai. (Blind identification of second order Hamerstein series.)

Trần Thái Sơn, Nguyễn Thế Dũng - Một phương pháp nội suy giải bài toán mô hình mờ trên cơ sở đại số gia tử. (A new method for solving the fuzzy model problem base on hedge algebra.)

Nguyễn Văn Vy, Đặng Văn Đức, Nguyễn Mạnh Đức - Mô hình đại số quan hệ của hệ thống hướng đối tượng. (A relational algebraical model of object oriented systems.)

Nguyễn Kim Anh - Một cách tiếp cận đối với phép dịch các câu truy vấn ngôn ngữ tự nhiên thành dạng logic. (An approach to translating natural language queries into logical form.)

\section{Volume 21, Number 4 (2005)}

Bùi Thế Hồng - Về một cải tiến ddoosi với lược đồ giấu dữ liệu an toàn và vô hình trong các bức ảnh hai màu. (A revision for secure and invisible data hiding in 2-color images.)

Phan Van Chung, Duong Tuan Anh - A query sublanguage for temporal clinical database systems and its implementation. (A query sublanguage for temporal clinical database systems and its implementation.)

Nguyễn Thế Bình - Đồ hình tổng quát và mối quan hệ với văn phạm cấu trúc câu. (General diagram and relation of general diagram with phrase-structure grammar.)

Nguyễn Văn Tam, Đào Văn Thành, Phạm Thanh Giang - Hệ thống thoại Internet an toàn. (The security internet phone system.)

Phạm Bá Quang, Đào Ngọc Kiên, Huỳnh Quyết Thắng - Mô hình phần mềm chịu lỗi BK-FTS: thử nghiệm, so sánh và đánh giá. (BK-FTS an architecture of fault tolerant software: implementation,comparision and evolution.)

Vu Duc Thi, Nguyen Hoang Son - Phản khóa và khóa tối thiểu của sơ đồ quan hệ. (Antikey and minimal keys of relation schemes.)

Nguyễn Bường, Nguyễn Thị Thu Thủy - Tốc độ hội tụ của nghiệm hiệu chỉnh cho bất đẳng thức biến phân hỗn hợp không chính quy. (Convergence rates in regularization for ill-posed mixed variational inequalities.)

Phạm Hạ Thủy - Xác định phần tử ngoại lai trong cơ sở dữ liệu quan hệ. (Detect the outliers in the relational database.)

\section{Tưởng nhớ GS. TSKH. Nguyễn Thúc Loan}

\section{Volume 22, Number 1 (2006)}

Nguyễn Thế Bình - Họ trìu tượng các nguồn. (Abstract family of sources.)

Hồ Thuần, Hoàng Thị Lan Giao - Khám phá phụ thuộc đa trị dựa vào ma trận phụ thuộc. (The discovery of multivalued dependencies based on dependency matrices.)

Phương Minh Nam, Trần Thái Sơn - Về một cơ sở dữ liệu mờ và ứng dụng trong quản lý tội phạm hình sự. (About a fuzzy database and his applications in criminal management.)

Phạm Đức Long, Phạm Thượng Cát - Công nghệ mạng nơ ron tế bào và ứng dụng. (Cellular neural networks and its applications.)

Phạm Hạ Thủy, Hoàng Xuân Huấn - Phát hiện phần tử ngoại lai trong cơ sở dữ liệu quan hệ nhờ phân tích hồi quy. (Detect outliers in relational databases by regression analyzing.)

Nguyễn Văn Hùng, Bùi Văn Thanh - Nghiên cứu thực nghiệm tính phân bố đều của các dãy số ngẫu nhiên,giả ngẫu nhiên và tựa ngẫu nhiên. (An emprical study on uniformly of random pseudorandom and quasi-random secquences.)

Nguyễn Mạnh Đức, Đặng Văn Đức - Về một cách tinh chế mô hình lớp UML. (On the method refinement for models of UML.) 
Nguyễn Văn Lâm, Lê Chí Quỳnh, Nguyễn Vũ Sơn - Hàm tương quan phi chu kỳ và độ phức tạp của các dãy phi tuyến dùng CDMA thé hệ mới. (Aperiodical corelation function and complexity (Equivalen linear sapan) of the nonlinear PN-sequences for 3. generator CDMA.)

Vũ Hoài Chương - Nghiên cứu thống kê động thái dân số Việt Nam thời kỳ 2003 qua 150 mô hình xu thế. (Statistical study on Vietnam population's dynamics in period 1878-2003 with 150 trend models.)

\section{Volume 22, Number 2 (2006)}

Phạm Thượng Cát - Những thành tựu đã đạt được trong nghiên cứu phát triển công nghệ tự động hóa 30 năm qua tại Viện Công nghệ thông tin. (Research and development of automation at the Institute of Information technology for past 30 years.)

Trần Đình Khang, Hoàng Thị Minh Tâm, Hồ Ngọc Vinh - Một số dạng tập mờ biểu diễn giá trị chân lý ngôn ngữ trong logic mờ. (On the fuzzy representation of the set of linguistic truth values in fuzzy logics.)

Vũ Đình Hòa, Đỗ Như An - Kết quả mới về đồ thị Hamilton tối đại. (New results about maximal Hamiltonian graph.)

Bùi Công Cường, Dương Thăng Long, Hoàng Việt Long - Hai tiếp cận tới bài toán xấp xỉ phi tuyến. (Two approaches to the nonlinear functions approximation problem.)

Vũ Mạnh Xuân, Nguyễn Thanh Thủy - Giải thuật di truyền mã hóa số thực với toán tử lai ghép SBX. (Real-coded Genetic Algorithms with Simulated Binary Crossover Operator.)

Nguyễn Thị Thanh Tân, Lương Chi Mai - Phương pháp nhận dạng từ viết tay dựa trên mô hình mạng nơ ron kết hợp thống kê từ vựng. (A new method for off-line word handwriting recognition using four layers neural-networks combined with vocabulary statistics.)

Phạm Việt Bình - Một số tính chất của phép toán hình thái và ứng dụng trong phát hiện biên. (Investigating properties of morphological operations and applying them into edge detection.)

Lê Thanh, Nguyễn Văn Ngọc, Nguyễn Thúc Hải - Sự phân ly trách nhiệm trong mô hình kiểm soát truy nhập dựa trên vai với rằng buộc thời gian. (Separation of duty in temporal constraint role-based across control model.)

Nguyễn Đức Lạng - Chuyển đổi môi trường tính toán song song cho mô hình dự báo thời tiết HRM. (Developing a new pararllel code in distributed memory computers for the weather forecast model HRM.)

\section{Volume 22, Number 3 (2006)}

Nguyen Hong Phong, Tran Gia Lich - Dòng chảy không ngừng sau vỡ đập. (The unsteady flow after dam breaking.)

Nguyễn Cát Hồ, Vũ Như Lân, Lê Xuân Việt - Một phương pháp diều khiển dựa trên đại số gia tử với tham số biến. (A method of control based on hedge algebras with boundary parameters.)

Vũ Đình Hòa, Đỗ Như An - Số đồ thị Hamilton tối đại. (The number maximal uniquely Hamiltonian graph.)

Dang Quang A, Le Tung Son - Phương pháp lặp giải một bài toán biến đổi với phương trình kiểu song điều hòa. (Iterative method for solving a boundary value problem for biharmonic type equation.)

Nguyen Thi Thu Thuy, Nguyen Buong - Xấp xỉ hữu hạn chiều cho bài toán cực trị đa mục tiêu không chỉnh các phiếm hàm lồi trong không gian Banach. ( Finite - dimensional approximation for ill-posed vector optimization of convex functionals in banach spaces.)

Đỗ Văn Thành - Phát hiện luật kết hợp mờ có độ hỗ trợ cực tiểu không giống nhau. (Mining fuzzy association rules with unequal minimum supports.) 
Phạm Việt Bình - Phát hiện biên dựa trên lọc trung bình và trung vị cục bộ. (Edege detection based on local average and median filtering.)

Hoàng Xuân Huấn, Nguyễn Thị Xuân Hương - Một mở rộng thuật toán phân cụm k-means cho dữ liệu hỗn hợp. (An extension of the k-means algorithm for mixed data.)

Nguyễn Kim Anh - Truy vấn cơ sở dữ liệu quan hệ sử dụng đồ thị khái niệm. (Querying relational databases using conceptual graph.)

Nguyễn Văn Tảo, Bùi Thế Hồng - Nâng cao chất lượng ảnh trong kỹ thuật thủy văn sử dụng miền tần số giữa của phép biến đổi DCT. (Improvement of the host image quality in the watermarking technique using the middle frequency domain of the DCT.)

\section{Volume 22, Number 4 (2006)}

Bùi Công Cường, Phí Anh Quân - Mạng nơ ron học tăng cường dựa trên quyết định để nhận dạng chân dung. (Reinforced learning in decision-based neural networks for face recognition.)

Vũ Như Lân, Vũ Chấn Hưng, Đặng Thành Phu - Kỹ thuật đại số gia tử nhận dạng mô hình dựa trên hệ luật. (The technique of hedge algebras for rule-based system identification.)

Đặng Quang Á, Vũ Vinh Quang - Phương pháp chia miền giải bài toán biên hỗn hợp mạnh. (Domain decomposition method for solving strongly mixed boundary value problems.)

Phan Thị Hoài Phương, Nguyễn Minh Hằng - Mô hình kết hợp thuật toán gen và phương pháp đơn hình ứng dụng trong bài toán cực tiểu hóa chi phí sản xuất. (A model combining genetic algorithm and simplex method for solving production expense minimizing problem.)

Đinh Thị Phương Thu, Hoàng Vĩnh Sơn, Huỳnh Quyết Thắng - Cải tiến giải thuật CYK cho bài toán phân tích cú pháp tiếng việt. (Proposed modifications of the cyk algorithm for the vietnamese parsing.)

Đỗ Năng Toàn - Tái tạo đối tượng 3 chiều từ hình ảnh hai chiều. (Reconstruct 3D objects from 2D images.)

Lê Hải Khôi, Nguyễn Lương Đống - Về toán tử trung bình và một số tính chất. (The averaging operations and their characteristics.)

Nguyễn Đức Lạng, Trần Gia Lịch, Lê Đức - Thuật toán song song tính dòng chảy hai chiều sử dụng lưới tam giác. (A parallel algorithm computing two-dimensional flows on triangular grids.)

Nguyễn Thiện Luận, Trần Hồng Quang - Phương pháp phân đoạn khi ra quyết định nhằm nâng cao độ chính xác trong lượng giá mức độ an ninh mạng. (Improve degree of correctness in process of network security assesment by using fuzzy sets in decision.)

\section{Volume 23, Number 1 (2007)}

Chi Nguyen, Nello Cristianimi - Phát hiện sự lựa chọn tự nhiên bằng phương pháp tính toán. (Computational detection of natural selection in gene family expansion and contraction.)

Nguyen Ngoc Tien, Nguyen Viet Kinh, Seong Rag Kim - Nghiên cứu kỹ thuật tách tín hiệu cho kênh đường xuống của hệ thống CDMA đa sóng mang. (A study on detection techniques for downlink in multi-carrier CDMA system.)

Nguyễn Lãm, Lý Quốc Ngọc, Dương Anh Đức - Kết hợp đặc trưng thị giác và ngữ nghĩa trong truy vấn video số dựa trên mô hình phân cấp dữ liệu. (Combining visual features and semantic concepts in digital video retrieval based on hierarchical data model.)

Nguyễn Cát Hồ, Phạm Thanh Hà - Giải pháp kết hợp đại số gia tử và mạng nơ ron RBF trong việc giải quyết bài toán điều khiển mờ. (The solution that uses combination between hedge algebra and RBF neural network in the multi-conditions fuzzy control method.)

Nguyễn Bường, Đặng Thị Hải Hà - Về tốc độ hội tụ trong hiệu chỉnh cho phương trình toán tử loại Hammerstaein đặt không chỉnh. (About convergence rates in regularization for ill-posed operator equations of hammerstein type.) 
Nguyễn Quý Minh Hiền, Phạm Quốc Huy - Một thuật toán gen cho thiết kế topology mạng có khả năng hồi phục. (A genetic algorithm for topological design of survivable networks.)

Lê Hữu Lập, Vũ Như Lân, Nguyễn Hồng Sơn - Một phương pháp thực AFij tại lõi bộ định tuyến trong mạng dịch vụ khác biệt. (A new method to implement afij at core routers in diffserv networks.)

Vũ Đức Thi, Phạm Hạ Thủy - Phụ thuộc hàm xấp xỉ và phần tử ngoại lai đối với phụ thuộc hàm. (Type 2 approximate functional dependency and the outliers with functional dependency.)

Lê Huy Thập - Phân mảnh trên giá trị lặp của các thuộc tính trong cơ sở dữ liệu quan hệ. (A fragmentation of the given relational database by group of the repeated values of the attributes.)

Volume 23, Number 2 (2007)

Nguyễn Bường, Đặng Thị Hải Hà - Phương pháp hiệu chỉnh liên tục cho phương trình toán tử không chỉnh loại Hammerstein. (Continuous regularization method for illposed operator equations of Hammerstein type.)

Nguyễn Cát Hồ, Nguyễn Công Hào - Một cách tiếp cận để đánh giá dữ liệu trong cơ sở dữ liệu mờ. (An approach for evaluating data in fuzzy databases.)

Hồ Thuần, Hoàng Thị Lan Giao - Mở rộng phị thuộc hàm và phụ thuộc đa trị. (A generalization of functional and multivalued dependencies.)

Đặng Huy Ruận, Vũ Trọng Quế - Độ phức tạp ôtômat hữu hạn của biểu thức chính quy hai phía. (The finite automates complexity degree of a double-side regular expression.)

Nguyễn Xuân Huy, Đoàn Văn Ban, Nguyễn Hữu Trọng - Phát triển thuật toán khai thác dữ liệu dựa trên bao đóng của các thuộc tính. (Developing an algorithm for data mining based on closed of attributes.)

Lê Xuân Cương, Đỗ Trung Tuấn, Đỗ Xuân Tiến - Chuẩn bị dữ liệu trong việc xây dựng cơ sở dữ liệu video số. (Preparing the data for building digital video databases.)

Huỳnh Quyết Thắng, Phạm Thị Quỳnh - Các giải thuật tìm kiếm và lựa chọn thành phần cots tối ưu theo các tiêu chí giá thành và dư thừa dữ liệu. (Algorithms for selecting software components cots with optimization by cost and by data redundancy)

Nguyễn Văn Long - Phụ thuộc dữ liệu trong cơ sở dữ liệu quan hệ với thông tin ngữ nghĩa. (Data dependencies in ralational vague linguistic data.)

Vũ Đức Thi, Trần Xuân Diệu - Phụ thuộc hàm xấp xỉ và xây dựng cây quyết định phụ thuộc hàm xấp xỉ. (Approximate dependencies using for building decision tree.)

Nguyễn Long Giang - Phát triển các giải thuật song song trong khai phá luật kết hợp. (Parallel algorithms development for association rule mining.)

\section{Volume 23, Number 3 (2007)}

Nguyễn Cát Hồ, Phạm Thanh Hà, Vũ Như Lân - Xác định trọng số tối ưu cho phép tích hợp trong phương pháp điều khiển mờ sử dụng đại số gia tử. (Use genetic algorithm to determine optimal weights of integrated operation in fuzzycontrol method using hedge algebras.)

Le Thanh Huong - Một cách tiếp cận trong phân tích cấu trúc diễn ngôn của văn bản (An approach in automatically generating discourse structure of text.)

Nguyen Hai Chau, Atsushi Kawai, Toshikazu Ebisuzaki - Tăng tốc thuật toán khai triển nhanh FMM trên máy tính chuyên dụng. (Special-purpose computer accelerated fast multipole method.)

Lê Mạnh Thạnh, Hoàng Bảo Hùng - Mô hình ước lượng chi phí xử lý truy vấn đối tượng trong cơ sở dữ liệu hướng đối tượng (A cost model for object-oriented query processing in object-oriented databases.) 
Vũ Hoài Chương, Nguyễn Công Điều - So sánh và kiểm định độ phân kỳ của các dãy và tập điểmtựa-ngẫu-nhiên một chiều. (Comparing and testing discrepancies of one-dimensional quasi-random sequences and point-sets.)

Nguyễn Hữu Trọng - Thuật toán khai thác tập thường xuyên hiệu quả dựa trên kỹ thuật phân lớp dữ liệu (Algorithm for exploitation the frequent itemset effective based on data subclass technology.)

Hồng Trung Dũng, Cao Hoàng Trụ - Dịch tự động truy vấn tiếng Việt sang đồ thị khái niệm (Automatic translation of Vietnamese queries into conceptual graphs.)

Trần Duy Anh - Phát hiện các hàm phụ thuộc xấp xỉ theo cách tiếp cận tập thô (Discovering approximate functional dependencies via the rough set approach.)

\section{Volume 23, Number 4 (2007)}

Lê Xuân Việt - Xây dựng mô hình mờ SISO dựa trên đại số gia tử. (Constructing siso fuzzy model based on hedge algebras.)

Vũ Thành Nam, Phan Trung Huy - Mã đàn hồi và một tiếp cận đại số. (Spring codes with algebraic approach.)

Đoàn Văn Ban, Lê Mạnh Thạnh, Lê Văn Tường Lân - Một cách chọn mẫu huấn luyện và thuật học để xây dựng cây quyết định trong khai phá dữ liệu. (One effective way of choosing training set and algorithm on building a decision tree for data mining.)

Nguyễn Kim Anh - Tích hợp ngữ nghĩa sử dụng các ontology hình thức. (Semantic integration using formal ontologies.)

Nguyễn Thanh Hải, Phạm Thế Long, Nguyễn Công Định - Phương pháp xây dựng các mô tả fourier cho từng phần hình dạng và một số tính chất. (A method of building fourier descriptors for partial shapes and some properties.)

Lê Hữu Bình, Võ Thanh Tú - Nghiên cứu cơ chế định tuyến trong mạng IP trên WDM có cấu trúc theo mô hình xếp chồng. (Study on the routing mechanisms in ip over wdm networks with overlay model.)

Nguyễn Ngọc Hà - Thuật toán giấu tin hỗn hợp. (A composed image data hiding algorithm.)

Nguyễn Thanh Tùng - Khám phá tập mục lợi ích cao trong cơ sở dữ liệu. (Mining high utility itemsets in databases.)

Đỗ Văn Thành - Giải pháp dự báo ngắn hạn về tăng trưởng kinh tế Việt Nam. (On a short-term forecast of Vietnam economy.)

\section{Volume 24, Number 1 (2008)}

Vu Duc Thi, Nguyen Hoang Son - Về họ trù mật của quan hệ trong cơ sở dữ liệu. (On the dense families of database relations.)

Nguyen Viet Anh, Nguyen Viet Ha, Ho Sy Dam - Xây dựng mạng xác xuất Bayesian Belief Network để tạo ra các tiến trình học trong hệ thống Adaptive Hypermedia. (Constructing a Bayesian belief network to generate learning path in adaptive hypermedia system.)

Nguyễn Cát Hồ, Nguyễn Công Hào - Phụ thuộc đơn điệu trong cơ sở dữ liệu mờ theo cách tiếp cận ngữ nghĩa lân cận của đại số gia tử. (Linear functional dependencies in fuzzy databases using semantics neighbourhood based on hedge algebras.)

Trương Minh Nhật Quang, Hoàng Kiếm - Cơ chế máy học chẩn đoán virus máy tính. (Machine learning mechanisms to diagnose computer virus.)

Nguyễn Kim Anh - Mô hình dữ liệu đối với các truy vấn định lượng. (A data model for quantified queries.)

Đỗ Văn Thành - Cơ sở dữ liệu chủ đề về kinh tế vĩ mô. (Macroeconomic data mart.) 
Nguyễn Duy Phương, Từ Minh Phương - Một thuật toán lọc cộng tác cho trường hợp ít dữ liệu. (A collaborative filtering algorithm for sparse data.)

Nguyễn Văn Long - Cơ sở phương pháp luận của phương pháp đánh giá bằng nhã ngôn ngữ. (A methodological foundation of the evaluation method using linguistic labels.)

Trần Thái Sơn, Lê Quốc Thái, Nguyễn Văn Nam - Đại số gia tử và bài toán săp xếp mờ tài liệu tiếng Việt. (Hedge algebras and problems of fuzzy ranking Vietnamese documents.)

\section{Volume 24, Number 2 (2008)}

Trần Đình Khang - Luật chuyển gia tử và tính chất bao hàm. (Rules of moving hedges and the subsumption property.)

Cù Thu Thủy, Đỗ Văn Thành - Một phương pháp mới về phân tích thị trường chứng khoán Việt Nam. (New resolution for analyzing Vietnams stock market.)

Nguyễn Duy Minh, Vũ Như Lân - Phương pháp điều khiển dựa vào việc định lượng đại số gia tử với bảng sam có điều kiện. (A control method based on quantifying hedge algebras with conditional sam table.)

Nguyễn Sỹ Dũng, Ngô Kiều Nhi - Tổng hợp hệ thống suy diễn neuro-fuzzy thích nghi (anfis) từ tập dữ liệu số. (Establishing an adaptive neuro-fuzzy inference system (anfis) based on a given numerical data set.)

Phan Thị Hoài Phương, Nguyễn Minh Hằng, Lương Chi Mai - Một cách tiếp cận thuật toán gen để giải bài toán phủ tập hợp. (A genetic algorithm-based approach to the set covering problem.)

Nguyen Hong Son, Le Huu Lap - Thủ tục báo hiệu không tường minh và tiêu chuẩn quyết định của các router phi trạng thái trong Diffserv domain. (Implicit signaling procedure and decisive criterion of stateless routers in diffserv domain.)

Nguyễn Kim Anh - Phép dịch truy vấn ngôn ngữ tự nhiên thành các truy vấn SQL sử dụng văn phạm ngữ nghĩa. (Translating natural language queries into SQL queries using semantic grammar.)

Vũ Đức Thi, Nguyễn Huy Đức - Khai phá tập mục thường xuyên cổ phần cao trong cơ sở dữ liệu lớn. (Mining share-frequent itemsets in large databases.)

Phạm Tuấn Minh, Nguyễn Thúc Hải - Một giải pháp lập lịch gói tin để đảm bảo yêu cầu chất lượng dịch vụ của các mạng WiMAX. (A QoS-oriented scheduling solution for WiMAX networks.)

\section{Volume 24, Number 3 (2008)}

Phạm Thanh Hà - Mở rộng độ đo tính mờ và ánh xạ ngữ nghĩa định lượng trên cơ sở giả thiết độ đo tính mờ của phần tử trung hòa khác không.

Vũ Đức Thi, Nguyễn Huy Đức - Thuật toán hiệu quả khai phá tập mục lợi ích cao trên cấu trúc dữ liệu cấy.

Nguyễn Thu Anh, Trần Thái Sơn, Lê Quốc Thái, Lê Ngọc Thắng - Xây dựng giải pháp tìm kiếm trong cơ sở dũ liệu ảnh với thông tin mô tả mờ.

Nguyễn Doãn Phước - Một phương pháp điều khiển ổn định BIBS thích nghị hệ song tuyến (bilinear) và ứng dụng vào điều khiển hệ các khớp nối cơ khí mềm.

Phạm Thượng Cát, Nguyễn Trần Hiệp - Điều khiển rô bốt theo nguyên lý trượt sử dụng mạng nơ ron. (Robust sliding mode control of manipulator using neural network.)

Nguyễn Vinh Quang, Chử Đức Trình, Trần Quang Vinh - Giám sát và Điều khiển từ xa hoạt động của vi kẹp sử dụng vi điều khiển và thị giác máy tính.

Ngô Đình Trí, Lê Thị Minh Nghĩa - Ước lượng các tham số ổn định và điều khiển của máy bay từ dữ liệu bay thử nghiệm. 
Nguyễn Văn Khang, Nguyễn Quang Hoàng, Lê Đức Đạt, Trần Hoàng Nam - Về một thuật toán điều khiển trượt rô bốt dư dẫn động.

\section{Volume 24, Number 4 (2008)}

Nguyễn Cát Hồ, Nguyễn Công Hào - Một phương pháp xử lý truy vấn trong CSDL mờ tiếp cận ngữ nghĩa lân cận đại số gia tử. (A method to processing query in fuzzy databases using neighbourhood based on helge algebras.)

Bui Cong Cuong, Le Quang Phuc, Nguyen Thi An Binh - Kết hợp phương pháp phân cụm mờ theo ngữ cảnh với thuật toán học có quên trong mạng nơron để sinh ra các luật mờ. (A combination of context-fuzzy clustering method and learning with forgetting algorithm in a neural network model to generating fuzzy rules.)

Vũ Đức Thi, Nguyễn Huy Đức - Khai phá hiệu quả tập mục lợi ích cao trong cỏ sở dữ liệu lớn. (Efficient mining of high utility itemsets in large database.)

Huỳnh Văn Đông, Trần Xuân Kiên, Nguyễn Công Định - Điều khiển backsteping thích nghi hệ thống truyền động điện có tính đến đàn hồi và khe hở phi tuyến. (Adaptive backsteping control of electrical transmission drives with elastic and unknown backlash nonlinearity.)

Phạm Thượng Cát - Điều khiển rô bốt $\mathrm{n}$ bậc tự do có nhiều tham số bất định trong không gian đề các. (Robust cartesian control of n-DOF manipulator with dynamic and Jacobian uncertainties.)

Phạm Văn Hiển, Thạch Lễ Khiêm, Lê Tấn Sỹ - Hiệu quả điều khiển linh hoạt SVC bằng thyristor để hãm dao động điện cơ trong hệ thống điện. (Effectiveness of SVC flexible control by thyristor to obstruct static oscillation.)

Đoàn Phúc Thịnh, Nguyễn Duy Phúc, Nguyễn Tân Tiến - Nghiên cứu điều khiển rô bốt hàn di động. (Study on control of two-wheeled mobile robot.)

Nguyen Truong Thanh, Nitin V. Afzulpurkar - Lập đường đi trong môi trường động cho rô bốt di động xử lý ảnh. (Dynamic path planning for a mobile robot using image processing.)

\section{Volume 25, Number 1 (2009)}

Phạm Thượng Cát, Nguyễn Văn Tính - Điều khiển lai lực/vị trí rô bốt n bậc tự do có nhiều tham số bất định trong khung tọa độ tay nắm rô bốt. (Hybride force/position control of n-DOF robot manipulators with uncertainties.)

Phạm Thanh Hà - Phương pháp lập luận mờ sử dụng đại số gia tử với ánh xạ ngữ nghĩa định dạng khoảng. (Fuzzy reasoning method based on hedge algebras using interval quantitative sematic mappings.)

Vũ Thái Luân, Đặng Quang Á - Về một khía cạnh ảnh hưởng của tham số đến bài toán xấp xỉ dữ liệu tán xạ sử dụng hàm cơ sở bán kính Multiquadric (MQ). (On influence aspect of parameter in scattered data approximation problem using multiquadric radial basis function.)

Nguyễn Hoàng Tú Anh, Hoàng Kiếm - Áp dụng kỹ thuật khai thác đồ thị vào bài toán phân loại văn bản. (Adapting graph mining techniques for text classification.)

Nguyễn Cát Hồ, Trần Thái Sơn, Dương Thăng Long - Tiếp cận đại số gia tử cho phân lớp mờ. (A novel hedge algebras based method for fuzzy classification.)

Hoàng Thị Lan Giao - Một thuật toán tìm tập rút gọn của bảng quyết định không đầy đủ. (An algorithm for computing a reduct of incomplete decision table.)

Trịnh Thị Thúy Giang, Lê Trọng Vĩnh, Hoàng Chí Thành, Nguyễn Thanh Thủy - Tối ưu đa mục tiêu trong việc lập lịch cho hệ thống tính toán lưới. (Multiobject optimization for scheduling in grid computing systems.) 
Phạm Anh Phương, Ngô Quốc Tạo, Lương Chi Mai - Kết hợp các bộ phận phân lớp SVM cho việc nhận dạng chữ việt viết tay rời rạc. (Vietnamese handwritten character recognition by combining SVM classifers.)

\section{Volume 25, Number 2 (2009)}

Bùi Công Cường, Hoàng Việt long, Phạm Hồng Phong - Ứng dụng hệ mờ phân cấp trong bài toán xấp xỉ hàm phi tuyến. (On the approximation of continous function by spline function hireachical fuzzy systems.)

Nguyễn Đức Lăng, Trần Gia Lịch - Sự ổn định của một sơ đồ sai phân dùng để giải phương trình truyền tải, khuyếch tán vật chất ba chiều và ứng dụng. (Stability of some difference schemes for solving the three-dimensional matter transport diffusion equation and applications.)

Vũ Đức Thi, Nguyễn Hoàng Sơn - Họ trù mật của lược đồ quan hệ và ứng dụng. (The dense families of relation schemes and its application.)

Phạm Trần Nhu, Hoàng Mạnh Hà - Bộ lọc triệt tần thích nghi sử dụng thuật toán LMS với kích thước bước có thể thay đổi và ứng dụng trong ghi tín hiệu điện não đồ. (An adaptive notch filter using LMS algorithm with variable step-size for ECC signals.)

Hoàng Chí Thành - Xây dựng hành vi tương tranh của hệ mạng hợp thành. (Constructing concurrent behaviours of composed net systems.)

Vũ Huy Hoàng, Đặng Văn Chuyết - Một số tính chất của tập T(e), một tập con đặc biệt của Z. (Some properties of the set T(e), a special subset of Z.)

Nguyễn Kim Anh - Phân loại tự động các kết quả truy vấn sử dụng các sở thích của người dùng. (Automatic categorization of query results using user preferences.)

Đoàn Văn Ban, Trương Ngọc Châu - Gom cụm các đối tượng trong cơ sở dữ liệu hướng đối tượng sử dụng ma trận khoảng cách. (Clustering objects for object-oriented database systems using distance matrices.)

Đặng Hữu Đạo, Nguyễn Minh Tuấn, Lê Huy Thập, Hoàng Đỗ Thanh Tùng - Nghiên cứu xác định các dạng báo cáo tổng hợp linh hoạt. (Identification of different types of dynamically generated reports.)

\section{Volume 25, Number 3 (2009)}

Trương Ngọc Châu, Đoàn Văn Ban - Tối ưu hóa các truy vấn đối tượng có chứa các biểu thức đường dẫn. (Optimization of object queries containing path expressions.)

Phan Thị Hoài Phương, Lương Chi Mai, Nguyễn Văn Hùng - Một thuật toán lai ghép giải bài toán cắt vật tư một chiều với nhiều kích thước vật liệu thô. (A hybrid algorithm for one-dimensional cutting stock problem with multiple stock sizes.)

Huỳnh Thị Thanh Bình, Nguyễn Đức Nghĩa - Các kỹ thuật lai ghép trong gói giải thuật di truyền giải bài toán cây khung nhỏ nhất với đường kính bị chặn. (Recombination operators in generic algorithm for solving bounded diameter minimum spanning problem.)

Hoàng Quang, Hồ Thị Thanh - Mở rộng phương pháp chuyển đổi mô hình time-er sang mô hình quan hệ. (Extension of method for converting timeer model to relational model.)

Đặng Hữu Đạo, Lê Hữu Nghị, Nguyễn Minh Tuấn, Hoàng Đỗ Thanh Tùng - Một quy trình hỗ trợ tạo lập báo cáo tổng hợp linh hoạt. (A supporting procedure for creating dynamically generated reports.)

Đào Văn Thành, Nguyễn Văn Tam, Vũ Duy Lợi - Phân tích đánh giá hiệu năng chuyển giao đối với Mobile IPv6. (Analysis and evaluation of MIPv6 handover.)

Phạm Minh Tuấn, Lê Hùng Linh - Điều khiển tốc độ động cơ không đồng bộ ba pha sử dụng mạng nơ ron nhân tạo. (Speed control of 3-phase asynchronous motor uisng artificial neural network.) 


\section{Volume 25, Number 4 (2009)}

Trần Văn Dũng - Về ngữ nghĩa đại số của các chương trình tổ hợp. (On the algebraic sematics of combinational programs.)

Nguyễn Cát Hồ, Lê Xuân Vinh, Nguyễn Công Hào - Thống nhất dữ liệu và xây dựng quan hệ tương tự trong cơ sở dữ liệu ngôn ngữ bằng đại số gia tử. (Unify data end establish similarity relation in lingustic databases upon helge-algebra-based.)

Huỳnh Quyết Thắng, Vũ Hoài Linh - Đánh giá độ sẵn sàng của phần mềm chịu lỗi áp dụng kỹ thuật rejuvenation và nvp hai phiên bản. (Evaluation the availability of fault-tolerent software applying rejuvenation and $n$-version programming techniques.)

Cù Thu Thủy, Đỗ Văn Thành - Phát hiện luật kết hợp với rằng buộc mục dữ liệu âm. (Mining association rules with negative item constraints.)

Đặng Hữu Đạo, Nguyễn Hoàng Hà, Nguyễn Minh Tuấn, Hoàng Đỗ Thanh Tùng - Về một quy trình phi chuẩn hóa cơ sở dữ liệu. (On a database denormalization process.)

Phạm Thượng Cát, Nguyễn Tuấn Minh - Phương pháp điều khiển bền vững cho hệ robotcamera bám mục tiêu di động. (Robust control of robot-camera system tracking moving object.)

\section{Volume 26, Number 1 (2010)}

Nguyễn Tăng Cường - Về tính ổn định ngẫu nhiên của hệ điều khiển đa cấu trúc. (On stability stochastic stability of multistructural control system.)

Nguyễn Tăng Cường - Về xây dựng một số tiêu chuẩn ổn định ngẫu nhiên cho hệ điều khiển đa cấu trúc. (Some stochastic stability criteria for multistructural control systems.)

Hồ Khánh Lâm - Phân tích kiến trúc nhớ đệm web kết hợp của mạng internet. (Analysis of internet hybrid web catching architecture.)

Phan Anh Phong, Trần Đình Khang - Biểu diễn tập mờ loại hai đại số gia tử. (A representation for hedge algebraic type 2 fuzzy sets.)

Trần Thái Sơn - Về một cách tính giá trị định lượng ngữ nghĩa của phần tử trong Đại số gia tử. (A method of computing quantifield sematic values of any element of heldge algebra.)

Dương Thăng Long - Một phương pháp xây dựng hệ luật mờ có trọng số để phân lớp dựa trên đại số gia tử. (A method for designing weighted fuzzy rules systems for classification based on hedge algebras.)

Nguyễn Thanh Tùng - Về một metric trên họ các phân hoạch của một tập hợp hữu hạn. (A metric on the set of partitions of a finite set.)

\section{Volume 26, Number 2 (2010)}

Luong The Dung, Ho Tu Bao - Nâng cao tính riêng tư trong phân cụm dữ liệu phân tán. (Enhancing Privacy in Distributed Data Clustering.)

Nguyễn Cát Hồ, Trần Thái Sơn, Dương Thăng Long, Trần Duy Hùng - Phương pháp tối ưu Pareto hệ luật mờ dựa trên đại số gia tử sử dụng giải thuật di truyền và ứng dụng vào bài toán phân lớp. (A genetic algorithm based Pareto optimization hedge-algebra-based fuzzy rules-sets.)

Trần Đình Khang, Tạ Quang Trung, Lê Anh Phương - Xây dựng ánh xạ ngược của gia tử. (Constructing inverse mappings of hedges.)

Vũ Đức Thi, Trịnh Đình Vinh - Alpha-phụ thuộc hàm và alpha-bao đóng trong mô hình cơ sở dữ liệu dạng khối. (Alpha-functional dependencies and alpha-closure in the database model of block form)

Huỳnh Quyết Thắng, Phạm Thị Quỳnh, Tạ Quang Dũng - Phương pháp xây dựng độ đo tái sử dụng của Web service. (A method for service reusability measuring.) 
Lê Hồng Phương, Nguyễn Thị Minh Huyền, Nguyễn Phương Thái, Phan Thị Hà - Trích rút tự động văn phạm LTAG cho tiếng Việt. (Grammar extraction LTAG for Vietnamese.)

Trịnh Thanh Bình, Trương Ninh Thuận, Nguyễn Việt Hà - Kiểm chứng sự tuân thủ về rằng buộc thời gian trong các ứng dụng phần mềm. (Checking the compliance of timing constraints in software applications.)

Lê Thị Kim Nga, Đỗ Năng Toàn - Phát hiện ảnh cắt/dán giả mạo dựa vào các đặc trưng bất biến. (Detecting copy/move forgery images based on invariant features.)

\section{Volume 26, Number 3 (2010)}

Phạm Thượng Cát - Xu thế phát triển rôbốt trên thế giới và tình hình phát triển rôbốt ở Việt nam hiện nay. (Robotic research trends in the world and robotic research and development in Vietnam.)

Phạm Minh Tuấn - Điều khiển tư thế bám vệ tinh với nhiều tham số bất định. (A tracking control of satellite attitude with uncertain parameters.)

Đào Văn Hiệp, Trần Xuân Thành - Một giải pháp điều khiển Exoskeleton. (A control solution for Exoskeleton.)

Nguyễn Đức Minh, Nguyễn Đức Thành, Dương Hoài Nghĩa - Điều khiển ổn định con lắc ngược sử dunghj mạng nơ ron. (Stabilizing inverted pendulum using neural networks.)

Phạm Đức Long - Xác định vị trí các giá đỡ hàng sử dụng cho xe tự động bốc xếp trong kho cảng. (Determining position and orientation of pallet used for controlling autonomous forklift in warehouse automation.)

Phan Đại Thành, Lê Phạm Minh Quân, Ngô Khánh Hiếu - Thiết kế và chế tạo mô hình quạt hướng trục dùng hai động cơ quay ngược chiều nhau. (Design and manufacture a testing model of the two-stage axial-flow fan.)

Đặng Văn Đức, Nguyễn Tiến Thành - Một phương pháp cải tiến tìm kiếm ảnh trên cơ sở hình dạng và ứng dụng trong GIS. (An improved technique for image retrive based on object shape and applycations to GPS.)

Nguyễn Thị Hương Thủy, Nguyễn Ngọc Minh, Nguyễn Ngọc Kỷ - Giải thuật phân đoạn ảnh chỉ bản vân tay mười ngón. (A ten-print card segmenting algorithm.)

Vũ Đức Thái - Vấn đề ổn định và tương đương của mạng CNN giải phương trình thủy lực hai chiều. (The stability and equivalence of cnn architecture for solving $2 \mathrm{~d}$ hydraulic equation.)

\section{Volume 26, Number 4 (2010)}

Hồ Ngọc Vĩnh, Phan Trung Huy, Đỗ Long Vân - Mở rộng mã và thuật toán kiểm định mã luân phiên và mã của các từ định biên. (Extension of codes and algorithms for alternative codes and codes of bounded words.)

Trịnh Đình Vinh, Vũ Đức Thi - Phủ của tập phụ thuộc hàm và vấn đề tựa chuẩn hóa trong mô hình dữ liệu dạng khối. (Cover of the set of functional dependencies and quasinorms in database model if block.)

Đoàn Văn Ban, Hồ Cẩm Hà, Vũ Đức Quảng - Phương pháp phát hiện các lớp bộ phận trong lớp đối tượng mờ. (A method for discovering component classes in fuzzy object classes.)

Đỗ Năng Toàn, Nguyễn Văn Huân - Một kỹ thuật tăng tốc biểu diễn tóc. (An algorithm for fast speeding in hair representation.)

Nguyễn Phùng Quang, Đào Phương Nam - Phân tích so sánh hai giải pháp điều khiển phi tuyến trong điều khiển động cơ tuyến tính loại đồng bộ - kích thích vĩnh cửu. (Comparative analysis of two nonlinear control designs to control permanent magnet excited synchronous linear motors.)

Cáp Thanh Tùng, Phạm Thượng Cát - Xử lý ảnh y tế 4D CT chịu nén sử dụng mạng nơ ron tế bào. (4D-CT medical compressible image processing using cellular neural network.) 
Nguyễn Thanh Nhựt, Chung Tan Lam - Hoạch định quỹ đạo bước cho rô bốt hai chân. (Walking planning for biped robot hubot.)

Nguyễn Thành Luân, Trần Thiện Phúc, Nguyễn Duy Anh, Nguyễn Tân Tiến - Nghiên cứu điều khiển theo vết đường hàn dùng cảm biến hồ quang quay. (Fuzzy based welding seam tracking control for gmaw with rotating arc sensor.)

\section{Volume 27, Number 1 (2011)}

Nguyễn Đình Hân, Hồ Ngọc Vinh, Phạm Trung Huy, Đỗ Long Vân - Thuật toán xác định tính chất mã của ngôn ngữ chính quy. (An algorithm for testing whether a regular language is a code.)

Trương Ngọc Châu, Đoàn Văn Ban - Tối ưu biểu thức điều kiện tìm kiếm trong các truy vấn đối tượng sử dụng các chỉ mục lồng. (Optimization technique for finding conditional expression using nested indexes.)

Nguyễn Quỳnh Diệp, Phạm Tho Hoan, Hồ Tú Bảo, Trần Đăng Hùng, Phạm Quốc Thắng - Phương pháp tái hiện mạng các chất chuyển hóa từ dữ liệu sinh học hệ thống. (Computational reconstruction of metabolic networks from high-throughput profiling data.)

Bui Cong Cuong, Pham Van Chien - Một kết quả thử nghiệm dùng hệ suy diễn mờ nơ ron thích nghi để dự báo gí chứng khoán. (An experiment result based on adaptive neuro-fuzzy inference system for stock price.)

Đặng Thanh Chương, Vũ Duy Lợi, Võ Viết Nhật Quang - Mô hình kết hợp giữa định tuyến lệch hướng và đường trễ quang fdl trong giải quyết nghẽn mạng chuyển mạch chùm quang obs. (Modeling analysis of deflection routing with FDLS to resolving contention problem in Obs networks.)

Trần Gia Lịch, Lê Đức - Mô hình thể tích hữu hạn trên lưới phi cấu trúc và ứng dụng trong tính toán dòng chảy hai chiều. (A finite volume model on unstructured meshes and application in computing two dimensional flows.)

Nguyễn Thị Thanh Vân, Phùng Mạnh Dương, Phạm Đình Tuân, Trần Quang Vinh - Hệ thống rô bốt tuần tra dựa trên logic mờ ứng dụng trong hệ tự động hóa tòa nhà. (Development of a fuzzy-based patrol robot using in building automation system.)

Nguyễn Minh Thạnh, Nguyễn Ngọc Lâm, Lê Hoài Quốc, Nguyễn Xuân Vinh - Tối ưu hóa thiết kế tay máy song song dùng thuật toán di truyền. (Optimization of parallel manipulators using genetic algorithms.)

\section{Volume 27, Number 2 (2011)}

Lê Huy Thập - Giải các bài toán trên cây toán tử đường ống bằng ma trận đặc trưng. (Solution of the problems on the pipelined operator tree using characteristical matix.)

Phan Anh Phong, Đinh Khắc Đông, Trần Đình Khang - Xây dựng hệ logic mờ loại 2 đại số gia tử. (A method for constructing hedge algebraic type-2 fuzzy logic systems.)

Đoàn Văn Ban, Hồ Cẩm Hà, Vũ Đức Quảng - Chuẩn hóa các lớp đối tượng trong lược đồ cơ sở dữ liệu hướng đối tượng mờ. (Normalizing object classes in fuzzy object-oriented database schema.)

Cù Thu Thủy, Hà Quang Thụy - Phát hiện luật kết hợp sporadic không tuyệt đối hai ngưỡng mờ. (Mining fuzzy imperfectly sporadic rules with two threshold.)

Lê Hoài Bắc, Nguyễn Kim Hưng, Lê Thị Hoàng Ngân - Mô hình chứng thực dựa trên ảnh vân tay. (Authenification scheme based on fingerprint images.) 
Nguyễn Long Giang, Vũ Đức Thi - Một phương pháp rút gọn thuộc tính trong bảng quyết định dựa trên entropy cải tiến. (An attribute reduction algorithm in a decision based on improved entropy.)

Vũ Hoài Chương - Những thử nghiệm tạo các dãy tựa ngẫu nhiên hai chiều. (Experimentation on generating two-dimensional quasi-random sequences.)

Nguyễn Đức Cương, Hoàng Anh Tú - Tính toán quỹ đạo vệ tinh có tính đến sự không cầu của Trái đất, lực cản khí quyển và véc tơ lực đẩy. (Satellites orbit calculation with consideration of nonspherical form of the Earth, atmospheric drag and thrust vector.)

Thông báo Hội nghị Toàn quốc lần thứ nhất về Điều khiển và Tự động hóa VCCA-2011. - (VCCA-2011 Call for papers.)

\section{Volume 27, Number 3 (2011)}

Nguyễn Long Giang, Vũ Đức Thi - Thuật toán tìm tất cả các rút gọn trong bảng quyết định. (Algorithm for finding all attribute reduction of a decision.)

Phan Thị Hà, Nguyễn Thị Minh Huyền, Lê Hồng Phương, Adam Kilgarriff - Nghiên cứu từ vựng tiếng Việt với hệ thống sketch engine. (Lexicographic study in sketch engine.)

Bùi Vũ Anh - Otomat khoảng trong lập lịch các chương trình cho hệ thống máy tính phân cụm. (Duration automation in scheduling program for a cluster computer system.)

Trần Bình Long, Trần Hanh - Phân lớp biểu lộ cảm xúc khuôn mặt dựa trên mô hình PZMIZMIPCARBFN. (Final expression classification based on pseaudo zernike moment invariant, zernike moment invariant, principal component analysis and radial basis function neural network.)

Nguyễn Văn Long, Hoàng Văn Thông - Vấn đề kết nhập thông tin biểu diễn bằng bộ 4 với ngữ nghĩa dựa trên đại số gia tử. (Information aggregation problem of 4 tuple linguistic based on hedge algebra.)

Vũ Huy Hoàng, Hồ Thuần - Mở rộng lược đồ ngưỡng của Shamir cho việc chia sẻ đồng thời nhiều bí mật. (Extending the Shamir threshold secret sharing scheme for sharing simultanneously several secrets.)

Đỗ Đức Đông, Hoàng Xuân Huấn - Về biến thiên của vết mùi trong phương pháp ACO method and novel algorithms. (On the behavior of pheromone trial in ACO method and novel algorithms.)

Ngô Hoàng Huy - Tổ hợp đường F0 và VTLN cho nhận dạng tên tiếng Việt. (On combining F0 contour and Vocal tract length normalisation for speech recognition of Vietnamese proper names.)

Phạm Thanh Giang, Phạm Minh Vĩ, Nguyễn Văn Tam - Phân tích vấn đề và đề xuất giải pháp nâng cao hiệu năng trong mạng ad-hoc đa chặng. (Problem analysis and solution for performance improvement in multi-hop ad hoc network.)

\section{Volume 27, Number 4 (2011)}

Nguyễn Hải Thanh, Phan Trung Huy - Phương pháp mô đun trên vành đặc số 2 và khả năng giấu tin tối đa theo các phương pháp CPT mở rộng. (Modules over rings of characteristic 2 and its application to maximality of secret data ratio in CPTE schemes.)

Đặng Thanh Chương, Vũ Duy Lợi, Võ Viết Minh Nhật - Mô hình phân tích sự kết hợp của chuyển đổi bước sóng có giới hạn và định tuyến lệch hướng trên mạng chuyển mạch chùm quang sử dụng chuỗi Markov 4 chiều. (Modeling analysis partial wavelength converters and deflection routing by using fourdimensional markov chains to resolving contention problem in obs networks.)

Đào Ngọc Phong, Nguyễn Xuân Hoài, Nguyễn Thanh Thủy, Nguyễn Quang Uy - Nghiên cứu và thử nghiệm lập trình gen trong bài toán tìm các xấp xỉ hàm Q-function. (An investigation of genetic programming for Q-function approximation.) 
Đoàn Văn Ban, Trương Công Tuấn, Đoàn Văn Thắng - Câu trả lời gần đúng cho truy vấn null trên mô hình cơ sở dữ liệu hướng dối tượng mờ thiếu thông tin. (Approximate answers to null queries with incomplete fuzzy information in object oriented database.)

Trần Thái Sơn, Đỗ Nam Tiến, Phạm Đình Phong - Luật kết hợp theo cách tiếp cận đại số gia tử. (Asssociate rull using heldge algebra approach.)

Zhi Quan Leong, Dev Ranmuthugala, Irene Penesis, Hung Duc Nguyen - Sử dụng phương pháp tái lập mạng động học chất lỏng tính toán (CPD) tạo các mô hình thủy động học để mô phỏng điều động hai vật thể ngầm chuyển động tương đới với nhau. (Computational fluid dynamics re-mesh method to generating hydrodynamic models for maneuvering simulation of two submerged bodies in relative motion.)

Trần Hoài Linh, Đinh Văn Nhượng, Đặng Văn Tuệ - Úng dụng mạng nơ ron logic mờ trong phát hiện sự cố của động cơ điện một chiều. (Defect detection in dc motors by applying neuro-fuzzy networks.)

Nguyễn Thị Mai Hương, Nguyễn Phùng Quang - Nghiên cứu khả năng trụ lưới của hệ thống phát điện chạy sức gió sử dụng máy phát không đồng bộ nguồn kép trong điều kiện điện áp lưới không đối xứng. (Improved the ride-through capability of wind power plants using doubly-fed induction generator under unbalanced voltage conditions.)

\section{Volume 28, Number 1 (2012)}

Nguyễn Công Định, Trần Ngọc Hà, Nguyễn Ngọc Khoa - Đánh giá hiệu quả phương pháp dẫn có lượng đón thay đổi thích nghi theo chuyển động của mục tiêu. (The effective evaluation of the guidance method which has the changed interception quantity that adaps to movement of target.)

Đặng Danh Hoằng, Nguyễn Phùng Quang - Điều khiển phi tuyến hệ thống phát điện chạy sức gió sử dụng máy phát không đồng bộ nguồn kép trên cơ sở hệ thụ động Euler-Lagrange và Hamilton. (Nonlinear control of wind power plants using double-fed induction generators based on passive Euler-Lagrange and Hamilton systems.)

Nguyễn Hoài Sơn, Nguyễn Văn Nhờ, Lê Văn Dương - Các kỹ thuật điều chế độ rộng xung hiện đại cho điều khiển tối ưu biến tần lai 3/3 NPC. (New PWM switching techniques for an optimum cascade $3 / 3$ NPC inverter operation.)

Nguyễn Quang Hoàng, Thái Phương Thảo - Giải bài toán động học ngược robot dư dẫn động bằng phương pháp chiếu tọa độ và chiếu vận tốc. (On solving inverse kinematics of redundant robotic manipulators by using coordinate and velocity projection methods.)

Đào Phương Nam, Nguyễn Phùng Quang - Cải tiến phương pháp xác định vị trí đỉnh cực của động cơ tuyến tính loại đồng bộ-kích thích vĩnh cửu trên cơ sở điều khiển lực đẩy thích nghi với sai lệch góc. (Initial pole position estimation of the permanent magnet-excited linear synchronous motors using force control.)

Đặng Quyết Thắng, Nguyễn Đình Hân, Phan Trung Huy - Xác định độ không nhập nhằng của ngôn ngữ chính quy theo ôtômát. (Determining unambiguous degree of regular languages by automata.)

Hà Hải Nam - Kết hợp giao diện tương tác và phương pháp thiết kế chiếu sáng đồ họa dựa trên mẫu sử dụng hàm mục tiêu dựa trên biến đổi Wawelet. (Interactive interface and lighting graphic sesign using Wavelet-based objective function.)

Truong Ninh Thuan, Trinh Thanh Binh, Vu Van Hieu - Hình thức hóa và kiểm chứng dịch vụ web sử dụng B. (Formalizing and checking web service discovery models using B.)

Lê Xuân Vinh, Trần Thiên Thành - Một số vấn đề về phụ thuộc đa trị trong cơ sở dữ liệu mờ chứa dữ liệu ngôn ngữ. (Some problems on multivalued dependencies in fuzzy databases with linguistic data.) 
Volume 28, Number 2 (2012)

Đoàn Văn Ban, Hồ Cẩm Hà, Võ Đức Quảng - Phụ thuộc hàm ddosis tượng mờ trong cơ sở dữ liệu hương đối tượng. (Fuzzy object functional dependences in fuzzy object-oriented databases.)

San Chanrathany, Lê Thanh Hương, Nguyễn Thanh Thủy, Nguyễn Hữu Thiệu - Trích rút thông tin tự động từ văn bản tiếng Việt. (Automatic information extraction in Vietnamese text.)

Nguyễn Long Giang, Nguyễn Thanh Tùng, Vũ Đức Thi - Một phương pháp mới rút gọn thuộc tính trong bảng quyết định không đầy đủ sử dụng metric. (A new method for attribute reduction to imcomplete decision table based on metric.)

Đặng Quyết Thắng, Nguyễn Đình Hân, Phan Trung Huy - Thuật toán mới xác định độ trễ giải mã của ngôn ngữ chính quy. (A new algorithm for determining deciphering delay of regular language.)

Vũ Đình Hòa, Nguyễn Hữu Xuân Trường - Chu trình Hamilton trong đồ thị $\sigma_{2}^{\star} \geq n$. (Hamilton cycle of graph $\sigma_{2}^{\star} \geq n$.)

Nguyễn Trung Tuấn - Độ đo tương tự hỗn hợp có trọng số MSM-R và một số kết quả thực nghiệm với bài toán phân lớp dữ liệu. (A mixed similarity measure based on rough sets theory (MSM-R) and some experimental results for data classification problem.)

Phạm Trần Nhu, Nguyễn Thị Quỳnh Lan, Hoàng Mạnh Hà - Xác định điều kiện để bảo toàn thông tin trong làm trơn phổ tín hiệu điện tim nhiễm nhiễu. (Determining conditions preserving information in smothing of a spectrum of noisy electro cardio graphy.)

Đào Văn Thành, Nguyễn Văn Tam, Vũ Duy Lợi - Cải tiến nâng cao hiệu năng cơ chế chuyển giao kết hợp FMIPv6 và HMIPv6. (Performance improvement of handover integration of FMIPv6 in HMIPv6.)

\section{Volume 28, Number 3 (2012)}

Rihard Bogush - Phát hiện khói trong video dựa trên chuyển động và tương phản. (Smoke detection in video based on motion and contrast.)

Lục Trí Tuyên, Nguyễn Văn Hùng, Thạch Thị Ninh, Phạm Quốc Vương, Nguyễn Minh Đức, Đào Xuân Kỳ - Một mô hình Markov ẩn trong dự báo chỉ số chứng khoán VN-Index. (A normal - hidden markov model model in forecasting stock index.)

Nguyễn Hữu Tài, Nguyễn Thị Hoàng Lan - Nghiên cứu cải tiến chất lượng nén ảnh trong LCD. (Research on compression image in LCD to improve image quality.)

Phạm Văn Hưởng, Nguyễn Ngọc Bình, Phạm Ngọc Thanh - Tối ưu hóa bộ nhớ bị chiếm đóng của phần mềm nhúng trong giai đoạn thiết kế. (Optimizing occupied memory of embedded software in the design phase.)

Binh Thanh Nguyen, Duc Huu Nguyen, Thuy Thanh Nguyen - G-ODE, một sự mở rộng của Apache ODE cho dịch vụ lưới. (G-ODE, an extension of the apache ODE for grid services.)

Trần Thái Sơn, Nguyễn Cát Hồ - Tiếp cận đại số gia tử trong xây dựng thang điểm ngôn ngữ dùng trong đánh giá. (Hedge algebraic approach in construction the language scale for assessment.)

Bùi Công Cường, Tống Hòang Anh, Bùi Dương Hải - Một số phép toán trên tập mờ trực cảm loại hai. (Some operations on type-2 intuitionistic fuzzy sets.)

Nguyễn Công Hào, Trương Thị Mỹ Lê - Mô hình cơ sở dữ liệu hướng đối tượng mờ dựa trên ngữ nghĩa đại số gia tử. (Fuzzy object-oriented databases model with hedge algebra based semantics.) 


\section{Volume 28, Number 4 (2012)}

Nguyễn Thị Thu Hương, Nguyễn Thúc Hải, Nguyễn Thanh Thủy - Kết hợp phân đoạn diễn ngôn với bộ phân tích cú pháp liên kết để phân tích câu ghép nhiều mệnh đề tiếng Việt. (Parsing complex-compound sentences with an extension of Vietnamese link parser combined with discourse segmenter.)

Minh-Tri Pham, Tat-Jen Cham - Cận trên cho sai số bất đối xứng của bộ phân loại kết hợp lồi. (Bounding the asymmetric error of a convex combination of classifiers.)

Phạm Văn Hưởng, Nguyễn Ngọc Bình - Thiết kế và sinh mã cho hệ thống nhúng dựa trên DSL và T4. (Embedded system design and code generation by using the DSL and T4.)

Hoàng Văn Thông, Nguyễn Cát Hồ, Nguyễn Văn Long - Một phương pháp tiến hóa sinh hệ luật mờ cho bài toán phân lớp với ngữ nghĩa thứ tự ngôn ngữ. (An evolutionary method to generate fuzzy rule-based system for classification problems with semantics order of language.)

Trần Thái Sơn, Nguyễn Cát Hồ, Phạm Đình Phong - Định lượng ngữ nghĩa khoảng của đại số gia tử với việc bổ xung một gia tử đặc biệt. (Interval quantifying mapping of hedge algebras with adding special hedge.)

Đặng Thanh Chương, Vũ Duy Lợi, Võ Viết Minh Nhật - Mô hình phân tích nút lõi chuyển mạch chùm quang với các quá trình đến renewal và poisson. (An analytical model of SPL-FeedForward OBS core nodes with mixed renewal and poisson process inputs.)

Nguyễn Chí Ngôn, Ngô Lê Ngọc Bích - Phát triển giải thuật điều khiển đèn giao thông thông minh. (Algorithm development of an intelligent traffic light control system.)

Phạm Văn Thương - Nâng cao hiệu quả của nguyên tắc hạn chế và bù băng thông trong mạng IP. (Improve efficiency of rate limitation and compensation principles in IP network.)

\section{Volume 29, Number 1 (2013)}

Tuấn Anh Lương, Khang Văn Nguyễn - Tính toán so sánh một vài phương pháp số giải bài toán động học ngược rô bốt song song dư dẫn động. (A comparisison of some numerical methods for computing the inverse kinematics of redundant parallel robots.)

Nguyễn Hải Hà, Phạm Trần Nhu - Khuyếch tán phi tuyến hỗn hợp dùng tensor cấu trúc. (Nonlinear diffusions and structure tensor in modelling to speckle noise reduction and edge enhancement in ultrasound images.)

Cung Trọng Cường, Võ Thanh Tú, Nguyễn Thúc Hải - Một giải pháp cải tiến cơ chế định tuyến DSR dựa trên tác tử di động trong mạng manet. (An innovative solution of dsr routing mechanism based on mobile agent in manet networks.)

Lê Hữu Bình, Lê Nguyên Bình, Hoàng Văn Võ - Đánh giá hiệu năng mạng chuyển mạch burst quang bằng mô hình giải tích toán học sử dụng nguyên lý hàng đợi $\mathrm{M} / \mathrm{M} / \mathrm{w} / \mathrm{w}$ và mô phỏng trên $\mathrm{OMNeT}++$. (Evaluating effectiveness of optical burst switching networks by analytical models using queuing principle $\mathrm{M} / \mathrm{M} / \mathrm{w} / \mathrm{w}$ and simulation on $\mathrm{OMNeT}++$.)

Phan Thanh Sơn, Dương Tử Cường - Trích chọn các tham số đặc trưng tiếng nói cho hệ thống tổng hợp tiếng Việt dựa vào mô hình Markov ẩn. (Extract speech feature vectors for HMM-based Vietnamese speech synthesis system.)

Đoàn Văn Ban, Trương Công Tuấn, Đoàn Văn Thắng - Các phụ thuộc đối tượng mờ dựa trên xấp xỉ ngữ nghĩa theo cách tiếp cận đại số gia tử. (Fuzzy dependencies in approximation semantic based on the hedge algebras approach.)

Hoàng Chí Thành - Nguyên lý kế thừa và một số bài toán dãy bị chặn. (Inheritance principle and some bounded sequence problems.)

Lưu Bích Hương, Bùi Thế Hồng - Một lược đồ thủy vân cơ sở dữ liệu quan hệ với dữ liệu phân loại. (A watermarking scheme for relational databases with categorical data.) 


\section{Volume 29, Number 2 (2013)}

Nguyen Thanh Phuong, Tran Dinh Huy, Ngo Cao Cuong, Ho Dac Loc - Một phương pháp đơn giản để điều khiển robot 2 chân với dáng đi ổn định. (A simple walking control method for biped robot with stable gait.)

Nguyen Thi Thanh Van, Phung Manh Duong, Tran Thuan Hoang, Tran Quang Vinh - Định vị cho robot sử dụng bộ lọc kalman mở rộng cải tiến với logic mờ và mạng nơ ron. (Mobile robot localization using fuzzy neural network based extended kalman filter.)

Chi Nguyen Van, Phuoc Nguyen Doan - Điều khiển bám quỹ đạo thích nghi với sai lệch nhỏ tùy ý cho hệ phi tuyến Euler-Lagrange đồng thời có tham số bất định và nhiễu đầu vào. (Adaptive tracking control of Euler-Lagrange nonlinear systems in the presence of uncertainty and input noise with guaranteed tracking errors.)

Parkhomenko V. P., Trần Văn Lăng - Nâng cao hiệu năng tính toán cho mô hình hoàn lưu tổng quát của khí quyển. (Improved computing performance and load balancing of atmospheric general circulation model.)

Bùi Vũ Anh, Phan Trung Huy - Ứng dụng một tích khoảng mới trong bảo mật. (Apply a new product of durations in security.)

Lục Trí Tuyên, Nguyễn Hữu Mùi, Vũ Đình Hòa - Phân tích tính hội tụ của thuật toán di truyền lai mới cho bài toán lập lịch job shop. (Convergence analysis of the new hybrid genetic algorithm for job shop scheduling problem.)

Cáp Phạm Đình Thăng, Ngô Đức Thành, Lê Đình Duy, Dương Chí Nhân, Dương Anh Đức - Xác định vị trí mắt người trong video bằng cách kết hợp dò tìm và theo vết. (Eye localization in video by combining eye detector and eye tracker.)

Đỗ Hoàng Sơn, Nguyễn Tấn Tiến - Nghiên cứu phát hiện vết nứt trên vỏ trứng cút dùng xử lý ảnh và mạng nơ ron. (Study on detection of crack on the quail egg shell using image processing and neural networks.)

\section{Volume 29, Number 3 (2013)}

Nguyễn Doãn Phước - Bàn về khả năng ứng dụng lý thuyết hệ phẳng vào phân tích và điều khiển hệ phi tuyến. (About the applicability of flat systems theory in analysis and control of nonlinear systems.)

Đàm Thanh Phương, Phạm Thượng Cát - Đồng bộ thích nghi mạng CNN hỗn loạn và ứng dụng trong bảo mật truyền thông. (Adaptive synchronization of chaotic CNN and applications to secure communication.)

Ngọc Trần Nguyên - Nhận dạng cử chỉ của bàn tay người theo thời gian thực. (Real-time hand gesture recognition.)

Nguyễn Đình Hòa, Nguyễn Doãn Phước - Tính chuẩn H-infinity của các hệ động học đa tác tử. (H-infinity norm computation of multi-agent dynamical systems.)

Phuong Tien Nguyen, Duc Van Dang - Dự đoán vị trí của đối tượng chuyển động bằng cách khai phá luật kết hợp của các mẫu hình di chuyển. (Predict the location of moving objects using mining association rules of movement patterns.)

Phan Tan Quoc, Nguyen Duc Nghia - Thuật toán bầy ong giải bài toán cây khung với chi phí định tuyến nhỏ nhất. (Bees algorithm for solving minimum routing cost spanning tree problem.)

Hieu Trung Huynh, Quan Dac Ho - Xác định hematocrit sử dụng mạng nơ ron được huấn luyện online dựa trên máy máy học cực độ. (Hematocrit estimation using online sequential extreme learning machine.) 
Ban Hà Bằng, Nguyễn Đức Nghĩa - Thuật toán di truyền lai ghép thuật toán đàn kiến giải bài toán cực tiểu hóa độ trễ. (A hybrid algorithm combining genetic algorithm with ant colony algorithm for the minimum latency problem.)

\section{Volume 29, Number 4 (2013)}

Hung Duc Nguyen, Sachith Malalagama, Dev Ranmuthugala - Thiết kế, mô hình hóa và mô phỏng phương tiện ngầm vận hành từ xa- Phần 1 (Design, modelling and simulation of a remotely operated vehicle - Part 1)

Lê Hùng Linh, Phạm Thượng Cát, Phạm Minh Tuấn - Điều khiển động cơ xoay chiều ba pha có nhiều tham số bất định sử dụng bộ ước lượng tốc độ. (A speed estimation-based controller for three-phase AC motors having uncertain parameters)

Phạm Đình Phong, Nguyễn Cát Hồ, Trần Thái Sơn, Nguyễn Thanh Thủy - Một phương pháp thiết kế hệ phân lớp mờ dựa trên việc mở rộng lượng hóa đại số gia tử (A fuzzy classifier design method based on the extended hedge algebras quantification)

Huỳnh Ngọc Tín, Hoàng Văn Kiếm - Đề xuất các phương pháp tính độ tương tự đỉnh dựa trên xu hướng, ứng dụng cho bài toán khuyến nghị cộng tác (New methods for calculating trend-based vertex similarity for collaboration recommendation)

Kieu Van Hung - Thuật toán phân tích nguyên tố đối với siêu mã (A prime decomposition algorithm for supercodes)

Ngoc Tan Le, Ngoc Tien Le, Dien Dinh - Dịch máy thống kê Pháp-Việt kết hợp thông tin gióng hàng phân đoạn ngữ (French-Vietnamese statistical machine translation combining with chunk alignments)

Lê Xuân Vinh, Trần Thiên Thành, Lê Xuân Việt - Về một số dạng chuẩn trong cơ sở dữ liệu mờ chứa dữ liệu ngôn ngữ (On some normal forms in the fuzzy databases with linguistic data)

Nguyễn Văn Huy, Lương Chi Mai, Vũ Tất Thắng - Áp dụng Bottle Neck Feature cho nhận dạng tiếng nói tiếng Việt (Applying Bottle Neck Feature for Vietnamese speech recognition)

Danh sách phản biện năm 2013 - (2013 Reviewers)

\section{Volume 30, Number 1 (2014)}

Thang Diep Cao, Hai Thuc Nguyen, Giang Linh Nguyen - Một cơ chế quản lý hàng đợi tích cực cải tiến VBLUE trên môi trường truyển video (The VBLUE queue management mechanism in video environment $\mathrm{PDF}$ )

Sam Chan Rathany, Lê Thanh Hương, Nguyễn Thanh Thủy, Nguyễn Thành Long, Trịnh Minh Dũng - Trích rút quan hệ giữa các thực thể từ văn bản tiếng Việt sử dụng phương pháp lan truyền nhãn (Relation extraction in vietnamese text using label propagation.)

Nguyen Van Huy, Luong Chi Mai, Vu Tat Thang, Do Quoc Truong - Nhận dạng tiếng Việt sử dụng âm vị có thanh điệu dựa trên mô hình phân bố đa không gian (Vietnamese recognition using tonal phoneme based on multi space distribution)

Nguyen Minh Hai, Nguyễn Minh Tuấn - Cách tiếp cận dịch máy thông kê dựa trên cú pháp giải bài toán tự động khôi phục dấu cho văn bản. (Statistical syntax-based machine translation approach to diacritization problem)

Lưu Bích Hương, Bùi Thế Hồng - Đảm bảo sự toàn vẹn của cơ sở dữ liệu quan hệ với các dữ liệu kiểu văn bản bằng kỹ thuật thủy vân. (Integrity protection for relation databases with text data by digital watermarking)

Đoàn Văn Ban, Phạm Minh Nhật, Lê Văn Sơn - Mô hình nền tảng máy chủ chia sẻ và bài toán vector packing trong cung cấp tài nguyên cho dịch vụ ảo hóa (A shared hosting platform model and the vector packing problem to resource allocation for virtual service) 
Nguyễn Văn Khang, Trịnh Quốc Trung - Điều khiển chuyển động rô bốt hai chân trong pha một chân trụ theo phương pháp trượt sử dụng mjang nơ ron (Motion control of biped robots in single support phase based on neural network sliding mode approach)

\section{Volume 30, Number 2 (2014)}

Nguyen Tung Linh, Pham Thuong Cat - Ứng dụng mạng nơ ron Hopfield cho bài toán tái cấu trúc lưới điện phân phối (Application of Hopfield neural network for distribution network's reconfiguration)

Nguyen Dinh That - Điều khiển trượt rời rạc cho lớp hệ hụt cơ cấu chấp hành có xét đến ảnh hưởng của nhiễu bị chặn. (Discrete-time sliding mode control for a class of underactuated mechanical systems with bounded disturbances)

Khoa Duy Le, Hung Duc Nguyen, Dev Ranmuthugala - Thiết kế, mô hình hóa và mô phỏng phương tiện ngầm vận hành từ xa- Phần 2 (Design, modelling and simulation of a remotely operated vehicle - Part 2)

Nguyễn Quỳnh Diệp, Phạm Thọ Hoàn, Hồ Tú Bảo - Các độ đo thông tin tương hỗ đa biến có điều kiện (Conditional multivariate mutual information measures)

Trần Thanh Phước, Đinh Điền - Dịch lại từ chưa biết dạng biểu thức số trong dịch thống kê Hoa-Việt (Retranslating number expression unknown word in Chinese-Vietnamese statistical machine translation)

Hung Van Le, Khang Dinh Tran - Một số kết quả bổ xung của lập trình logic mờ ngôn ngữ (Further results of fuzzy linguistic logic programming)

Bùi Vũ Anh - Đơn định và tối thiểu hóa otomat khoảng (On the determining and minimizing problems of the duration automata)

Tran Duy Anh - Biểu diễn phụ thuộc hàm xấp xỉ theo phân hoạch, ma trận phân biệt được và luật kết hợp (Representation of approximate functional dependencies using partitions, discernibility matrix and association rules)

Nguyen Chi Hieu - Mô hình khai thác đặc tính ngôn ngữ đích để rút trích cụm danh từ song ngữ Anh-Việt (A model for exploiting the target language characteristics to extract bilingual base noun phrases)

\section{Volume 30, Number 3 (2014)}

Nguyen Thi Thuy Loan, Đỗ Trung Tuấn, Nguyễn Hữu Ngự - Khai thác luật phân lớp két hợp trên cơ sở dữ liệu phân tán (Mining Class Association Rules in Distributed Datasets)

Vu Minh Tuan, Tran Quang Anh, Ha Quang Minh - Đánh giá một số kỹ thuật phát hiện thư rác ứng dụng thuật toán xếp hạng người dùng trong mạng thư điện tử tại trường đại học Hà Nội (Evaluating spam detection techniques using ranking algorithm in email network at Hanoi University)

Pham Hong Phong, Bui Cong Cuong - Vài phép toán gộp ngôn ngữ trực cảm (Some intuitionist linguistic aggregation operators)

Hoàng Văn Thông, Nguyễn Cát Hồ, Nguyễn Văn Long - Một phương pháp sinh hệ luật mờ Mamdani cho bài toán hồi qui với ngữ nghĩa Đại số gia tử (An evolutionary method to generate Mamdani rule-based systems with hedge algebra based semantics for regression problems)

Nguyễn Văn Trung, Phan Bá Trí, Hoàng Hữu Hạnh - Tích hợp ontology với tiếp cận lý thuyết đồng thuận (New approach for ontology matching using consensus theory)

Nguyễn Thái Dương, Huỳnh Thị Thanh Bình, Ngô Hồng Sơn - Giải thuật heuristic và di truyền giải bài toán định tuyến đa điểm trên mạng cảm biến không dây nhiệm vụ tuần hoàn (Heuristic and genetic algorithms for solving minimum-energy multicasting problem in duty-cycled wireless sensor networks) 
Le Van Vinh, Tran Van Lang, Tran Van Hoai - Phương pháp đếm l-mer mới cho vấn đề phân loại trình tự metagenomic dựa trên độ phong phú (A novel l-mer counting method abundance-based binning of metagenomic reads)

Le Anh Tu, Nguyen Quang Hoan, Le Son Thai - Mạng nơron SOM có giám sát phân tầng áp dụng cho bài toán phân lớp (Hierarchy supervised SOM neural network applied for classification problem)

\section{Volume 30, Number 4 (2014)}

Celebrating 30 years of Journal of Computer Science and Cybernetics: 1984-2014

Somló János - Review paper: An overview and the time-optimal crusing trajactory planning

Nguyen Phung Quang - Review paper: general overview of control problems in wind power plants

Le Hoa Nguyen, Keum-Shik Hong - Lyapunov-based synchronization of two coupled chaotic Hindmarsh-Rose neurons

Nguyen Ngoc Son, Ho Pham Huy Anh - Hybrid PD and adaptive backstepping control for self-balancing two-wheel electric scooter

Dao Lam, Shuhui Li, and Donald Wunsch - Hidden Markov model with information criteria clustering and extreme learning machine regression for wind forecasting

Nguyen Phi Le, Nguyen Khanh-Van - On hole approximation algorithms in wireless sensor networks

Tran Thai Son, Nguyen Tuan Anh - Improve efficiency of fuzzy association rule using hedge algebra approach

Bui Cong Cuong - Picture fuzzy sets

Editorial Boards of Journal of Computer Science and Cybernetics: 1984-2014

Papers published in Journal of Computer Science and Cybernetics: 1984-2014 